\title{
Articles
}

\section{RECONCILING AGENCY FEE DOCTRINE, THE FIRST AMENDMENT, AND THE MODERN PUBLIC SECTOR UNION}

\author{
Courtlyn G. Roser-Jones
}

\begin{abstract}
Few institutions have done more to improve working conditions for the middle class than labor unions. Their efforts, of course, cost money. To fund union activities, thousands of collective bargaining agreements across the nation have long included provisions permitting employers to require employees to pay "fair share" or "agency" fees. In public unions - when the employer is the government - this arrangement creates tension between two important values: the First Amendment's protection against compelled expression and the collective benefits of worker representation. When confronted with this tension forty years ago in Abood v. Detroit Board of Education, the Supreme Court struck an uneasy compromise, allowing public sector unions to recoup expenses for collective bargaining but not for political activity. For decades, the decision has been a lightning rod with some scholars calling for its reversal and others insisting on its preservation. In the meantime, the realities of modern public sector collective bargaining have changed, and First Amendment jurisprudence has evolved. The Supreme Court, which recently granted certiorari in Janus v. AFSCME, now has the opportunity to reconsider Abood's fragile compromise.

This Article offers a new way forward within the First Amendment that honors the importance of both union activity and free expression. It proposes a method to reconcile these twin interests while also updating the doctrine to account for state legislative efforts, modern union realities, and First Amendment jurisprudential developments. The Article argues that agency fees should be brought into step with current political contribution and campaign finance jurisprudence. Under this middle-ground approach, some agency fees, but only those that are "closely drawn" to avoid unnecessary expressive infringement, will remain lawful. This approach may not satisfy those who ardently oppose agency fees of any kind or those who want Abood's rule fully upheld. Still, it emerges as the best way forward through a difficult terrain: It avoids the false dichotomy between union and political activities, respects state legislatures that craft innovative collective bargaining statutes, and grounds public sector agency fees with other coherent aspects of First Amendment jurisprudence.
\end{abstract}


AUTHOR-William H. Hastie Fellow, University of Wisconsin Law School. J.D., Notre Dame Law School, 2013; B.A., The Pennsylvania State University, 2010. I am immensely grateful for comments and feedback received from several faculty members at the University of Wisconsin Law School. Thank you to Miriam Seifter, Gwyn Leachman, John Ohnesorge, Rob Yablon, Carin Clauss, and Anuj Desai. For helpful comments on earlier versions of this Article, I also thank Martin H. Malin, Charlotte Garden, and the participants in the New and Emerging Voices in Workplace Law faculty workshop at the Association of American Law Schools annual meeting. Special thanks to the editors of the Northwestern University Law Review. Any errors are mine alone.

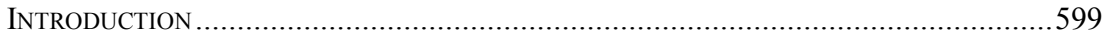

I. The Origins of Agency Fees in Collective Bargaining..............................605

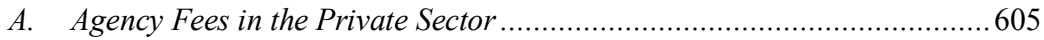

B. Agency Fees and the Private Sector Trilogy of Hanson, Street,

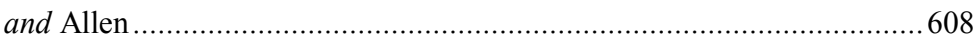

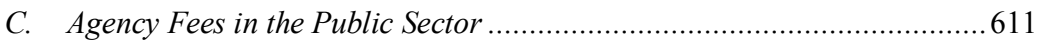

II. Nonjudicial Changes to Public Unions and Collective Bargaining IN THE YEARS SINCE ABOOD .............................................................................62 622

A. The Early Differences Between Private and Public Employment and Collective Bargaining: "[A] [V]ery [F]at [M]an [S]tuffed into a [L]ittle Lord Fauntleroy [S] uit".....

B. The Internal Evolution: Public Sector Unions and

"Professional Unionism".....

C. The Impact of Widening the Bargaining Scope in the Public Sector.......... 629

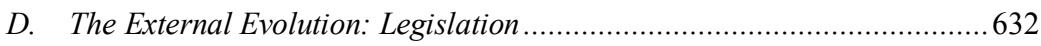

E. The External Evolution: Public Perception .................................................636

III. The First AmEnDMENT's Evolution After ABOOD ........................................643

A. Compelled Contributions as Compelled Speech in Campaign Finance...... 644

B. Compelled Third-Party Payments in Other Areas of the Law................... 648

IV. Reconciling Modern First Amendment Precedent with ABood And

Future Public Sector Agency Fee CASEs.....................................................651

A. Adopting a Compelled Contribution Framework Respects the States'

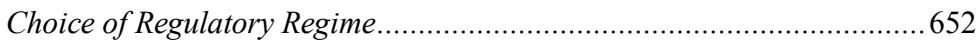

B. Adopting a Compelled Contribution Framework and Lesser Scrutiny Standard Is True to the First Amendment Doctrine ................................ 653

C. Adopting the Compelled Contribution Model Means Courts Will Not

Have to Choose Between Objecting Payers' and Unions' Rights .............. 654

D. Suggestions for "Closely Drawn” Statutory Frameworks........................655 


\section{INTRODUCTION}

For forty years, the law of public sector collective bargaining has teetered on a single precedent, reflecting an uneasy compromise. Under the approach established in Abood v. Detroit Board of Education, ${ }^{1}$ public employers and unions may enter into limited "agency shop" agreements as a means for unions to recoup their collective bargaining and contractrelated expenses. Unions may charge nonmembers "agency" or "fair share" fees in "exclusive representation" regimes on the grounds that nonmembers also obtain the benefits of collective bargaining. ${ }^{2}$ In contrast, unions are forbidden from using agency fees to cover expenses incurred to express their ideological or political views because requiring nonmembers to subsidize such expressive activities would violate their First Amendment rights. ${ }^{3}$ This compromise, hinging on the distinction between collective bargaining and political activities, has proven to be as divisive as it has been enduring. ${ }^{4}$

For decades, the scholarly literature on Abood has generally fallen into two distinct camps. On one side, critics have lambasted the decision as inconsistent with First Amendment principles, theorizing that agency fees compel the expression of nonmembers. ${ }^{5}$ On the other side, scholars have defended Abood's compromise as a justified means of promoting state government interests in efficient labor relations and preventing "free riders." As the Supreme Court prepares to consider a direct challenge to

1431 U.S. 209, 221-22 (1977).

2 Id. at 222; see also Chi. Teachers Union, Local No. 1 v. Hudson, 475 U.S. 292, 301 (1986); infra Section I.A (explaining exclusive representation and the exclusive bargaining representative's status as representative of all bargaining unit employees).

3 Abood, 431 U.S. at 222, 234-35; see also U.S. CONST. amend. I. The First Amendment commands that "Congress shall make no law . . abridging the freedom of speech." The Court has read the word "speech" broadly, frequently using it interchangeably with communicative "expression." E.g., Texas v. Johnson, 491 U.S. 397, 406-07 (1989). Protection for nonexpressive conduct that facilitates speech, such as group association and financial contribution rights, is derived from this freedom. E.g., Boy Scouts of Am. v. Dale, 530 U.S. 640, 644 (2000) (describing a right of expressive association).

4 Compare Knox v. Serv. Emps. Int'l Union, Local 1000, 567 U.S. 298, 311 (2012) (describing Abood's justifications as "something of an anomaly," but declining to overrule it), with id. at 335 (Breyer, J., dissenting) (disagreeing with the majority's characterization of Abood as anomalous, and describing the lines Abood draws and the balance it strikes as reflective of the Court's general evaluation of claims that a condition of public employment violates the First Amendment).

5 See, e.g., Daniel R. Levinson, After Abood: Public Sector Union Security and the Protection of Individual Public Employee Rights, 27 AM. U. L. REV. 1 (1977); Hugh L. Reilly, The Constitutionality of Labor Unions' Collection and Use of Forced Dues for Non-Bargaining Purposes, 32 MERCER L. REV. 561 (1981).

6 See, e.g., Lehnert v. Ferris Faculty Ass'n, 500 U.S. 507, 556 (1991) (Scalia, J., concurring in part and dissenting in part); Norman L. Cantor, Forced Payments to Service Institutions and Constitutional Interests in Ideological Non-Association, 36 RUTGERS L. REV. 3, 6 (1983); Matthew Dimick, Labor Law, New Governance, and the Ghent System, 90 N.C. L. REV. 319, 354 \& n.187 (2012) (citing Joe C. 
Abood and the agency fees it permits this term in Janus v. AFSCME, these twin views must be meaningfully revisited.

Both of these traditional camps overlook two key developments. First, public sector labor statutes and union activity look very different now than they did four decades ago. Second, First Amendment jurisprudence has evolved to protect not only familiar conceptions of free speech but also emerging interests in association and spending. These developments foreclose any effort to neatly overrule Abood on free speech grounds.

This Article proposes a better way to conceptualize agency fees and a better way for courts, unions, and reformers to navigate the complex intersection of public unions and individual expressive rights within an existing First Amendment framework. ${ }^{7}$ It suggests that agency fees be brought into step with current political contribution and campaign finance jurisprudence by viewing compelled contributions as the mirror image of contribution restrictions. In this framework, instead of limiting agency fees to those germane to collective bargaining, courts would limit agency fees to those reasonably necessary to perform the union's statutory duties as an exclusive bargaining representative. Under this "statutory duties" framework, agency fees subsidizing union activities that arguably infringe on payers' rights would be tolerated. But the collective bargaining statute permitting these activities and agency fees must be "closely drawn" to

Davis \& John H. Huston, Right-to-Work Laws and Free Riding, 31 ECON. INQUIRY 52 (1993)); Cynthia Estlund, Are Unions a Constitutional Anomaly?, 114 MiCH. L. REV. 169, 174-75, 186 (2015); Levinson, supra note 5. The term "free riders" in this context refers to nonunion employees who obtain the benefits of collective bargaining without incurring its costs. See Abood, 431 U.S. at 225-26; see also Harris v. Quinn, 134 S. Ct. 2618, 2656 (2014) (Kagan, J., dissenting) (pointing out that free ridership creates a uniquely severe "collective action problem" because, with the union required to negotiate benefits for both employees who pay and those who do not, "not just those who oppose but those who favor a union have an economic incentive to withhold dues; only altruism or loyalty-as against financial self-interest - can explain their support"). For more labor relations perspectives on the relationship between collective bargaining and free riders, see generally KURT L. HANSLOWE ET AL., Union Security in Public EMployment: Of Free Riding AND Free AsSOCIATION (1978). For other perspectives, see also MANCUR OlSON JR., THE LOGIC OF COLleCtive ACTION (1965) (economic perspective on free riders); Robert Albanese \& David D. van Fleet, Rational Behavior in Groups: The Free-Riding Tendency, 10 ACAD. MGMT. REV. 244 (1985) (organizational theorists' analysis of free riders and their impact on group productivity); Gary N. Chaison \& Dileep G. Dhavale, The Choice Between Union Membership and Free-Rider Status, 13 J. LAB. RES. 355 (1992) (empirical analysis of the overall impact of free riders on labor and industrial relations).

7 This Article assumes the threshold applicability of the First Amendment in public sector agency fee claims, and limits its exploration of legal alternatives to within the First Amendment's boundaries. It resigns itself to the First Amendment's use because that is what the Supreme Court has done for over forty years. However, I have reservations as to whether compelled agency fees are expressive enough to implicate a First Amendment constitutional starting point. 
avoid unnecessary abridgements and match a "sufficiently important [government] interest."

Bringing agency fees in line with campaign finance jurisprudence has several virtues. It logically tethers the doctrine to other modern First Amendment principles while still respecting Abood's foundational judgment that some forms of public sector agency fees may be constitutional. Political contribution jurisprudence also fits the agency fee context because it allows courts to recognize that monetary contributions can be expressive, without automatically imposing the standard of strict scrutiny that attends to pure political speech. ${ }^{9}$ Furthermore, political contribution jurisprudence is flexible enough to recognize the political tone of some union activities, while also giving deference to the expertise of state legislatures that have weighed a host of legitimate interests in crafting their collective bargaining statutes.

While some of the most persuasive commentators and the current Court have reviewed agency fees in the public sector through a First Amendment analysis, their approach either erroneously defines the conduct of agency fee payments as pure political expression, or as contributions triggering an "exacting scrutiny" standard of review. ${ }^{10}$ Once such an approach is taken, strict or exacting scrutiny dooms the states' interests, notwithstanding state legislatures' efforts to tailor agency fees and collection procedures to meet government interests in public sector collective bargaining. ${ }^{11}$ That the government faces a heightened burden when it singles out pure political speech is a relatively uncontroversial principle. But that limited or compelled contributions are permitted the

\footnotetext{
${ }^{8}$ McCutcheon v. FEC, 134 S. Ct. 1434, 1444 (2014) (quoting Buckley v. Valeo, 424 U.S. 1, 25 (1976)).

9 See Buckley, 424 U.S. at 21

10 Knox v. Serv. Emps. Int'l Union, Local 1000, 567 U.S. 298, 314 (2012); Martin H. Malin, The Evolving Law of Agency Shop in the Public Sector, 50 OHIO ST. L.J. 855, 858-59 (1989); see also Harris, $134 \mathrm{~S}$. Ct. at 2639 (in which the majority appears to endorse Knox's "exacting scrutiny" standard, despite professing that "no fine parsing of levels of First Amendment scrutiny is needed" for the facts of the case).

11 See Nixon v. Shrink Mo. Gov't PAC, 528 U.S. 377, 400 (2000) (Breyer, J., concurring) (noting the strong presumption against constitutionality that accompanies "strict scrutiny" analysis); see also McCutcheon, 134 S. Ct. at 1444 ("Under exacting scrutiny, the Government may regulate protected speech only if such regulation promotes a compelling interest and is the least restrictive means to further the articulated interest."). "Exacting scrutiny" is merely a linguistic twist on the familiar strict scrutiny standard, and in practice the two analyses and outcomes are the same. See id. (exacting scrutiny as implicitly amounting to strict scrutiny); United States v. Alvarez, 567 U.S. 709, 724 (2012) (plurality opinion) (equating "exacting scrutiny" with "most exacting scrutiny" and both with the standard strict scrutiny test); Buckley, 424 U.S. at 66, 68 (describing "exacting scrutiny" as "[t]he strict test," and including a discussion of "least restrictive means" in its analysis, a hallmark of the strict scrutiny test).
} 
same First Amendment freedoms as pure political speech is an anomalous, and antiquated, feature of agency fee jurisprudence.

This Article's approach also avoids the strained dichotomy between ordinary union activities and political expression. When the Court decided Abood, public sector collective bargaining statutes were still in their infancy. Because these early statutes resembled the private sector model, the majority's belief that one could readily distinguish political and collective bargaining expenses in both sectors was justified. ${ }^{12}$ But in today's current collective bargaining climate, public union activities are harder to categorize. Public sector collective bargaining can be political when it extends to issues of public policy such as classroom size and teacher tenure. Similarly, political activities like lobbying can relate to collective bargaining, such as when legislation is proposed for the sole purpose of limiting the permissible bargaining subjects in public sector employment. ${ }^{13}$ Moreover, according to the Court's dicta in Harris v. Quinn, even the most quintessentially traditional collective bargaining subjectwages - can reach important political issues in the public sector, particularly in an age of ballooning state payrolls and unbalanced budgets. ${ }^{14}$

Fortunately, states' collective bargaining laws have evolved into specifically customized balancing acts of competing interests. Many of them remove issues of public policy from the scope of public sector collective bargaining, establish notice and "opt-in/out" agency fee procedures, and restrain agency fees to a prescribed proportionate amount in order to limit unnecessary constitutional abridgments..$^{15}$ Thus, Abood's true flaw is that its dated analysis leaves no room for respect and consideration of modern legislative initiatives concerning public sector collective bargaining and agency fees.

To be sure, this compelled contribution alternative to agency fee analysis in the public sector will not fully satisfy either of the original hardline scholarly camps. Fair compromises rarely do. Admittedly, limiting

\footnotetext{
12 See Abood v. Detroit Bd. of Educ., 431 U.S. 209, 223, 229 (1977).

13 See id.; see also Lehnert v. Ferris Faculty Ass'n, 500 U.S. 507, 522 (1991) (holding that agency fees may only be used to subsidize lobbying activities within the limited context of facilitating contract ratification or implementation). Lehnert is a prime example of this strained dichotomy between union activities and political expression. The product of a badly fractured Court, Lehnert was written by justices with divergent views as to the political nature (and agency fee chargeability) of six different categories of union expenditures.

14 See Harris, 134 S. Ct. at 2632.

15 E.g., IND. CODE $\S \S 20-29-6-3$ to 20-29-6-4 (2011) (limiting the scope of collective bargaining); N.J. STAT. ANN. § 33:14A-5.5 (West 2017) (limiting agency fees to a proportionate amount); WASH. REV. CODE. ANN. § 42.17A.495 (West 2017) (replacing opt-out agency fee requirement with an annual opt-in requirement); Wis. STAT. ANN. § 111.91 (West 2017); see also infra Section II.C.
} 
agency fees to cover those expenses reasonably necessary to perform the statutory duties of an exclusive bargaining representative provides a narrower set of circumstances than Abood's germane-to-collectivebargaining rule permits. Conceivably, under this new approach, courts will look specifically at the language in the collective bargaining statute at issue and permit agency fees only for bargaining and contract administrative activities related to the statute's permissive and mandatory bargaining subjects. Unions would thus be excluded from charging agency fee payers for organizing activities, lobbying designed to expand the scope of collective bargaining, extra-unit litigation pools, and a number of other union expenses that were once arguably chargeable to agency fee payers under Abood. However, the current Court insists that all agency fees are expressive and refuses to grant broad "government-qua-employer" latitude to states' determinations that permitting agency fee collection as part of their collective bargaining statute best manages their public workforce. ${ }^{16}$ This suggests that, in a future challenge, agency fees used to cover germane-to-collective-bargaining expenses are already lost. As such, reimagining Abood through a compelled contribution framework that limits agency fees to the costs of performing statutory duties certainly paints a brighter picture than a contra-Abood world that prohibits them entirely.

For some longtime opponents of Abood, the framework proposed here probably does not go far enough to protect agency fee payers' First Amendment rights. Viewing compelled agency fees as significant infringements on an objector's expressive interests, these opponents purport to apply the most stringent forms of judicial scrutiny to all political expressions including agency fees. Those who advocate for Abood's demise purely for First Amendment doctrinal consistency, however, should find it difficult to reconcile such paramount protections of individual objecting-payer speech with the expressive rights of unions themselvesrights that unions logically have after Citizens United $v$. FEC. ${ }^{17}$

\footnotetext{
16 Harris, 134 S. Ct. at 2639; see also id. at 2653. The ability to use agency fees to cover these union expenses, like the rest of the chargeable expenses under the current Abood doctrine, is gone if Abood is overturned and agency fees in the public sector are held unconstitutional. See Garcetti v. Ceballos, 547 U.S. 410, 418 (2006); Pickering v. Bd. of Educ., 391 U.S. 563, $574-75$ (1968). The "government-qua-employer" principle refers to the Court's attempts to place the government in the same position as private employers when it comes to basic employment matters. Harris, $134 \mathrm{~S}$. Ct. at 2653. Consistent with this notion, the government has broader discretion to restrict an employee's words and actions when it acts as employer than when it acts as sovereign. But see id. at 2641 (noting that the Supreme Court has never "seen Abood as based on Pickering balancing").

17558 U.S. 310, 361 (2010); see Benjamin I. Sachs, Unions, Corporations, and Political Opt-Out Rights After Citizens United, 112 CoLUM. L. REV. 800, 802 (2012) (noting that campaign finance laws have always constrained the political spending of unions and corporations equally). Presumably, when the Court recognized the political speech rights of corporations under the First Amendment in Citizens
} 
This Article's intervention is timely. The Court recently granted review in Janus v. AFSCME to consider whether to overrule Abood and invalidate public sector agency fees under the First Amendment. ${ }^{18}$ Justice Neil Gorsuch, who replaced Justice Antonin Scalia in April 2017, has expressed a desire to clarify the level of scrutiny applicable to contribution limits - and a general awareness of the discontinuity within the Court's evolving First Amendment doctrines. ${ }^{19}$ Thus, reexamining the prevailing approach to public sector agency fees with the Court's full complement of Justices and the added presence of Justice Neil Gorsuch presents an opportunity to clarify some of the doctrine's ambiguities, and to bring it in accord with modern public union activities, statutory frameworks, and First Amendment principles.

Part I begins this effort by addressing the origins of agency fees and agency shop agreements in both the public and private sectors of employment. It starts by discussing the statutes and legislative materials associated with early collective bargaining in the private sector and examines the Supreme Court cases attending to agency shop agreements and fees. It then highlights the Court's reliance on private sector case analysis in the public sector agency fee challenge, Abood v. Detroit Board of Education, and illustrates how this reliance rendered Abood's First Amendment analysis incomplete. Furthermore, this Part discusses the Court's procedural additions to the workings of Abood several years later in Chicago Teachers Union, Local No. 1 v. Hudson. ${ }^{20}$ It concludes with a discussion of the Court's most recent decisions on agency fees in order to highlight the concerns which current Supreme Court Justices have expressed in trying to reconcile current First Amendment doctrine with public sector agency fees.

\footnotetext{
United, it also reinforced the same constitutional rights of unions. See also Catherine L. Fisk \& Erwin Chemerinsky, Political Speech and Association Rights After Knox v. SEIU, Local 1000, 98 CORNELL L. REV. 1023, 1026-28 (2013) (observing the inconsistency between Citizens United and the line of agency fee cases, in that Citizens United's "recent expansion of the rights of corporations to speak over the objections of dissenting members cannot be squared with Knox's expansion of the right of dissenters to restrict union speech").

18851 F.3d 746 (7th Cir. 2017), cert. granted sub nom. Janus v. AFSCME 138 S. Ct. 54 (Sept. 28, 2017) (No. 16-1466) (Illinois state employees asking the Court to overrule Abood on First Amendment grounds). Like Friedrichs v. California Teachers Ass'n, 136 S. Ct. 1083 (2016), in which an eightJustice Court deadlocked 4-4, the Janus litigation is funded by the National Right to Work Legal Defense Fund. Adopting a deliberate litigation strategy, the Janus appellants conceded that Abood is controlling law in the lower courts, inviting a ruling against them on the basis of the pleadings. This strategy is used to get cases to the Supreme Court as quickly as possible.

${ }^{19}$ E.g., Riddle v. Hickenlooper, 742 F.3d 922, 930 (10th Cir. 2014) (Gorsuch, J., concurring) (confessing "some uncertainty about the level of scrutiny the Supreme Court wishes us to apply to [a] contribution limit challenge").

20475 U.S. 292 (1986).
} 
Part II examines the historical evolution of public sector unionism since Abood was decided in 1977. It addresses the push to transplant the private sector legal model into the public sector and the early premises and assumptions this push rested on. Part II also expands upon the differences in private and public sector employment and explains how these differences have changed in response to evolutions in public sector collective bargaining and union activities. Finally, Part II explains the most recent legislative attacks on public sector collective bargaining and public union responses.

Part III explains the underlying First Amendment principles and precedents that affect the public sector agency fee doctrine, such as individual speech and association rights. This Part then argues that after close examination, the modern precedents and rationales behind most of these areas of law support a compelled political contribution framework and standard of review.

Finally, Part IV describes a better alternative to overruling Abood in Janus: retuning public sector agency fee analysis to the frequencies of compelled contributions and "closely drawn" scrutiny. Such a retuning would remove the focus on agency fees as "speech," or union activities as "political," and instead zero in on the state's collective bargaining statute. Agency fees would thus represent only a proportionate share of expenses necessary to perform the duties of an exclusive bargaining agent as defined in the statute. In describing this trimmed agency fee alternative that tailors chargeable expenses to the statutory duties, this Article proposes viable avenues for public unions and legislative bodies to construct an efficient regulatory scheme, establish a collective bargaining environment, and limit unnecessary constitutional infringements. These avenues include nontraditional statutory language, chargeability models, organizational schemes, and mechanisms for nonmember participation and voice.

\section{ThE ORIGINS OF AGENCY FEES IN COLLECTIVE BARGAINING}

The sources of agency fee doctrine in both the public and private employment sectors should be briefly summarized for perspective.

\section{A. Agency Fees in the Private Sector}

Federal law governs agency shop agreements and other labor matters in most industries of private sector employment. As part of the New Deal initiatives, Congress enacted the first comprehensive federal labor statute, 
the National Labor Relations Act (NLRA or the Wagner Act), in 1935. ${ }^{21}$ The NLRA sought to promote the rights of workers to unionize, or designate representatives of their own choosing for the purpose of bargaining collectively over terms and conditions of employment. ${ }^{22}$ Under the NLRA, once employees in a bargaining unit properly certified a labor organization or representative, employers were required to bargain collectively with (and only with) the certified representatives of their employees. ${ }^{23}$ This duty to bargain collectively encompassed two American labor law doctrines that remain fundamental: "good faith bargaining" and "exclusive representation." 24

The doctrine of exclusive representation made it an unfair labor practice for employers to bargain with employees who were not designated representatives of a certified union. ${ }^{25}$ It strengthened the union's role within the bargaining process by designating exclusive representation as the sole path to bargaining, but it also limited individual employees' rights to enter into employment agreements themselves. ${ }^{26}$ Because of this limitation, the Supreme Court reasoned that exclusive representation creates a duty for the

${ }^{21}$ National Labor Relations Act, 29 U.S.C. $\S 151-169$ (1935); see also Leon H. Keyserling, The Wagner Act: Its Origin and Current Significance, 29 GeO. WASH. L. REV. 199, 203 (1960). Other New Deal legislation included such working improvements as regulating child labor, creating the eight-hour workday, and establishing the social safety net featuring social security.

2229 U.S.C. § 151. New Deal law reformers, like President Franklin D. Roosevelt, campaigned on an economic platform in direct opposition to the "trickle down" approach of prior administrations, and the NLRA's promotion of collective bargaining reiterated Roosevelt's Keynesian policy of investing in and empowering the working class. Keynesian economics advocates for the expansion of the welfare state and for the government to step in to assist the economy generally in times of economic depression by buying things itself. See Gerald Friedman, American Labor and American Law: Exceptionalism and Its Politics in the Decline of the American Labor Movement, 11 LaW Culture \& Human. 30, 39 (2015).

2329 U.S.C. $\S \S 159(a), 158(a)(5)$. For union election and certification procedures, see 29 U.S.C. $\S 159$ (c).

24 See 29 U.S.C. 158(d) (requiring the parties to "meet at reasonable times and confer in good faith with respect to wages, hours, and other terms and conditions of employment").The NLRA also states that once a labor organization is properly selected according to the procedures established within the Act, that labor union "shall be the exclusive representative of all the employees in such unit for the purposes of collective bargaining in respect to rates of pay, wages, hours of employment, or other conditions of employment." Id. §159(a). See also Clyde W. Summers, Exclusive Representation: A Comparative Inquiry into a "Unique" American Principle, 20 COMP. LAB. L. \& POL'Y J. 47, 47 (1998) (referring to the principle of exclusive representation as "[t]he fundamental ordering principle which shapes American labor law and collective bargaining").

25 See Medo Photo Supply Corp. v. NLRB, 321 U.S. 678, 683-84 (1944). Under the NLRA, to obtain exclusive representation status, at least a majority of bargaining unit employees during a certification election must endorse a union. 29 U.S.C. § 159(c).

${ }^{26}$ See J. I. Case Co. v. NLRB, 321 U.S. 332, 338 (1944) ("The very purpose of providing by statute for the collective agreement is to supersede the terms of separate agreements of employees with terms which reflect the strength and bargaining power and serve the welfare of the group."). 
union to negotiate fairly on behalf of all represented employees. ${ }^{27}$ This duty of fair representation entitles all represented employees to equal application of the contract terms for which the union bargained with the employer. ${ }^{28}$

Since fair representation meant that all covered employees were presumably benefitting from the union's services and bargained-for contract terms, the NLRA allowed for unions and employer contracts to include union security agreements. The NLRA's provisions initially permitted several forms of union security agreements, including "closed shops" that required represented employees to join and remain members of the union as a condition of employment and "agency shops" that required nonmember employees to pay fees to a union for services rendered as their bargaining representative. ${ }^{29}$ The Act permitted unions to seek such security to promote "labor peace" and prevent represented employees from "free riding," or benefitting from the union representation afforded to all employees in a bargaining unit without paying for it. ${ }^{30}$

Twelve years after the NLRA became law, Congress met to discuss what it perceived to be a corrective response to some of the Act's collective bargaining policies. ${ }^{31}$ The NLRA's allowance for all types of union security agreements had led to allegations of unrestrained union power and abuse, and amending that allowance was at the top of Congress's agenda. ${ }^{32}$ Thus Congress - inclined to swing the pendulum of power back towards employers but recognizing the value some form of union security had on stabilizing the collective bargaining process-passed the Labor

\footnotetext{
${ }^{27} I d$. at 336.

28 See Steele v. Louisville \& Nashville R.R., 323 U.S. 194, 202-04 (1944). Although in Steele the Supreme Court applied the duty of fair representation under the Railway Labor Act (RLA), the Court's reasoning made clear that the duty applied equally under the NLRA. The Court, without opinion, confirmed this application to the NLRA. Syres v. Oil Workers International Union, Local No. 23, 350 U.S. 892 (1955); see also Railway Labor Act, 45 U.S.C. § 152 (1926); infra note 34.

29 In addition to closed shops and agency shops, there are several other more obscure types of agreements made during collective bargaining that fall under the general heading of "union security." See Charles Hanson et Al., The Closed Shop : A Comparative Study in Public Policy and TRADE UNION SECURITY IN BRITAIN, THE USA AND WEST GERMANY 121-23 (1982) (defining several other forms of collective agreements including the "union shop," the "preferential shop," "[m]aintenance of membership," and "[c]heck-off agreements").

${ }^{30}$ Int'l Ass'n of Machinists v. Street, 367 U.S. 740, 762-63 (1961) (discussing decisive past congressional hearings regarding the cost of exclusive representation and the burden of nonmembers who participate in the benefits without contribution).

31 See J. Michael Guenther, Note, Labor Law - Union Security - The Agency Shop and State Right-to-Work Laws, 35 NOTRE DAME L. ReV. 547, 547-48 (1960).

32 See id. at 547; see also NLRA, 29 U.S.C. § 158(a) (2012). Section 158(a) of the Wagner Act's provision that "nothing in this chapter... or in any other statute of the United States, shall preclude an employer from making an agreement with a labor organization... to require as a condition of employment membership therein" permitted all forms of union security agreements. Id.
} 
Management Relations Act (LMRA or the Taft-Hartley Act) in 1947.33 The LMRA, among other things, prohibited all forms of union security agreements except for agency shop agreements. ${ }^{34}$ Furthermore, $\S 14(b)$ of the LMRA allowed individual states to restrict all forms of union security agreements, including agency shops, within their own jurisdiction. ${ }^{35}$

\section{B. Agency Fees and the Private Sector Trilogy of Hanson, Street, and Allen}

The Supreme Court's first three constitutional challenges related to agency fees arose in the private sector under the Railway Labor Act (RLA), prior to public sector employees securing any significant collective bargaining rights. ${ }^{36}$ In Railway Employees' Department v. Hanson, the Court dismissed a First Amendment association claim, finding no evidence on the record that requiring employees to finance an exclusive bargaining representative that engaged in political activities "force[d] men into ideological and political associations which violate their right to freedom of

33 Pub. L. 80-101, 61 Stat. 136 (1947) (codified in scattered sections of 29 U.S.C.). Section 8(a)(3) of the Taft-Hartley Act amended $\S 8(3)$ of the Wagner Act, the relevant provision allowing for agency shop agreements.

34 Id. Taft-Hartley added the following language to the original Section 8(3) proviso:

[t]hat no employer shall justify any discrimination against an employee for nonmembership in a labor organization (A) if he has reasonable grounds for believing that such membership was not available to the employee on the same terms and conditions generally applicable to other members, or (B) if he has reasonable grounds for believing that membership was denied or terminated for reasons other than the failure of the employee to tender the periodic dues and the initiation fees uniformly required as a condition of acquiring or retaining membership.

Id.; see also Norman L. Cantor, Uses and Abuses of the Agency Shop, 59 NOTRE DAME L. REV. 61, 61 n.2 (1983) ("Although the statutory language refers to union 'membership' as a condition of employment, the NLRA has been interpreted to refer to 'financial core membership' rather than full union membership. Thus what appears to be a union shop authorization is actually an agency shop authorization.") (citing 601 F.2d 980 (9th Cir. 1979); Local Union No. 749, Int'1 Bhd. of Boilermakers v. NLRB, 466 F.2d 343, 345 (D.C. Cir. 1972); NLRB v. Gen. Motors Corp., 373 U.S. 734, 741-42 (1963); United Stanford Emps. Local 680 v. NLRB; Wine \& Liquor Store Emps., Local 122, 261 N.L.R.B. 1070 (1982)).

3529 U.S.C $\S 164($ b). Eleven states passed laws restricting union security agreements either before or contemporaneously with the passage of the Taft-Hartley Act. See Railway Labor Act, 45 U.S.C. $\S 152$ (2012). While the LMRA governs labor relations in most private sector industries, the major exceptions are the railway and airline industries, which are governed by the RLA. Although the original RLA was actually enacted in 1926 - before the LMRA and the NLRA - for the last seventy years many of its provisos have been amended to mirror the LMRA and homogenize labor law in all private industries. Four years after enacting the LMRA, Congress amended the union security provisions in the RLA to permit agency shop agreements between employers and unions in the railroad industry, notwithstanding any state law to the contrary. 45 U.S.C. $\S 152$; S. REP. NO. 81-2262, at 1 (1950). The RLA union security provision was modeled after $\S 8(\mathrm{a})(3)$ of the LMRA and is intended to embody identical constraints. See S. REP. No. 81-2262, at 1; see also Lykins v. Aluminum Workers Int'1 Union, 510 F. Supp. 21, 25 (E.D. Pa. 1980) (refusing to accept a difference between the NLRA's union security clause and precedent and the RLA's).

36 See 45 U.S.C. $\S 152$. 
conscience, freedom of association, and freedom of thought." ${ }^{37}$ Hanson involved employees under a closed shop agreement who simply did not want to join the union or pay any related dues. ${ }^{38}$ When it rejected defining compulsory payments to a union as per se violations of associational freedoms, the Hanson court did not resolve the free speech implications that might arise if such collected fees were used for purposes unrelated to collective bargaining. In declining to decide this issue, the Court noted that "if the exaction of dues, initiation fees, or assessments is used as a cover for forcing ideological conformity ... this judgment [would] not prejudice the decision in that case." 39

Five years later, the Court was confronted with the issue Hanson had reserved in International Ass'n of Machinists v. Street. ${ }^{40}$ In Street, a group of Georgia employees claimed that a portion of their compelled union fees went towards the union's financing of political causes they opposed, in violation of their First Amendment speech rights. ${ }^{41}$ Determined to avoid answering the constitutional question, a plurality of the Court interpreted the relevant provisions in the RLA as prohibiting such political uses of fees because they were completely unrelated to the purpose behind collective bargaining. ${ }^{42}$ In his plurality opinion, Justice William Brennan reasoned

37351 U.S. 225, 236 (1956). Because the record in Hanson provided little detail as to the specific uses of agency fees, the Court noted that agency fees in this case "is no more an infringement or impairment of First Amendment rights than there would be in the case of a lawyer who by state law is required to be a member of an integrated bar." Id. at 238; see also infra Section III.3.

38 Hanson, 351 U.S. at 227. In addition to a dismissal on First Amendment grounds, the Hanson Court also dismissed a challenge to agency shop provisions as a violation of the right to work liberty interest grounded in the Due Process Clause of the Fifth Amendment. Id. at 235. In evaluating both the First Amendment and due process challenges, the Hanson Court first determined that it had jurisdiction because the RLA's preemption of state statutes that prohibit agency fee agreements was sufficient state action to subject the provision of a contract between a private union and a private company to constitutional scrutiny. $I d$. at 232 ("If private rights are being invaded, it is by force of an agreement made pursuant to federal law which expressly declares that state law is superseded. In other words, the federal statute is the source of power and authority by which any private rights are lost or sacrificed." (citation omitted)); see also Crawford v. Air Line Pilots Ass'n Int'l, 870 F.2d 155, 160 (4th Cir. 1989) (rejecting the argument that subsequent Supreme Court decisions have overruled the finding of state action in Hanson).

39 Hanson, 351 U.S. at 238.

40367 U.S. 740 (1961).

41 Id. at $744-45$.

$42 I d$. at 749-50, 768, 770 ("[Section] 2, Eleventh is to be interpreted to deny the unions the power claimed in this case."). Although not part of the plurality opinion, four justices in Street did address the constitutional issue. Justice Harlan joined Justice Frankfurter's dissent and rejected the First Amendment claim finding that payments in return for representational services even when used to promote workers' interests by political means did not significantly infringe upon fee payers' rights to speak, think, and associate as they pleased. Id. at 805-06 (Frankfurter, J., dissenting). On the other hand, Justices Hugo Black and William Douglas, each writing separately, maintained that the use of compelled fees for political causes seriously violated an objector's First Amendment freedom to speak, 
that Congress's purpose in drafting the union security provisions of the RLA was not to vest "unions with unlimited power to spend exacted money" but rather to eliminate "free riders" and to equally distribute "the burden of maintenance by all of the beneficiaries of union activity." ${ }^{\prime 3}$ Thus, because "promot[ing] the propagation of political... concepts and ideologies" was outside of the scope of the intended policies behind the statutory purpose (preventing free riders and ensuring labor peace), union fees could not be used for this intent over a fee payer's objection. ${ }^{44}$

The Court decided in Street that compulsory union fees collected to support the collective bargaining activities of a union acting as an exclusive representative do not violate free association rights but that union dues that are used to support political causes could violate free speech rights. In doing so, it forced a hard line of permissibility between the two categories of collected union fees-those made to cover collective bargaining expenses (agency or fair share fees) and those used for political expenditures. Justice Brennan went on to acknowledge that there may be some union activities that do not neatly fit into either of the Court's articulated categories. ${ }^{45}$ The Street Court, however, provided "no view" as to where the line should be drawn for these expenditures when an employee objects to subsidizing them with her fees. ${ }^{46}$ Like its predecessor, the Street Court willingly left a palpable chasm in its compelled union fees jurisprudence.

Speaking for the Court two years later in Brotherhood of Railway \& Steamship Clerks v. Allen, ${ }^{47}$ Justice Brennan reaffirmed his position in Street that union fee objectors cannot be forced to support political ideologies. Although decided on procedural grounds, Allen found that the RLA prohibits unions from using an employee's fees to support political

\footnotetext{
think, and support causes of their choice. Id. at 778 (Douglas, J., concurring); id. at 788 (Black, J., dissenting).

${ }^{43}$ Id. at 766-68 (plurality opinion) (citation omitted). Furthermore, on agency shop fees Justice Brennan contended:

Its use to support candidates for public office, and advance political programs, is not a use which helps defray the expenses of the negotiation or administration of collective agreements, or the expenses entailed in the adjustment of grievances and disputes. In other words, it is a use which falls clearly outside the reasons advanced by the unions and accepted by Congress why authority to make unionshop agreements was justified. Id. at 768 .

${ }^{44}$ Id. at 744; see id. at 763 (quoting Ry. Emps.' Dep't v. Hanson, 351 U.S. 225, 235 (1956)). In distinguishing political activities from union activities that are germane to collective bargaining, the Street Court acknowledged that there may be some activities that are both unnecessary to effectuate collective bargaining and are neither political nor ideological. Id. at 768-69.

${ }^{45} I d$. at $769-70$.

$46 I d$. at 769 .

47373 U.S. 113 (1963).
} 
causes that the payer opposes and that in the case of opposition the union bears the burden of providing "a division of the union's political expenditures from those germane to collective bargaining." 48 While handing down this procedural burden to unions, the Allen Court, like the Street Court before it, also reasserted the validity of objectors being compelled to pay agency fees for collective bargaining purposes. ${ }^{49}$

Although incomplete, the Hanson, Street, and Allen trilogy provided the foundational doctrine for agency shop agreements and fees in the private sector. They established for purposes of future analysis that union expenditures fall into three categories: (1) those germane to collective bargaining, (2) those made in support of political causes and activities, and (3) all other expenses that fall into neither of the above categories. Because they support the government's purpose behind union security provisions allowing agency shop agreements, expenses in the first category are chargeable to an objecting fee payer. Expenses within the second category are not. Finally, the cases establish that it is the union's responsibility to determine which part of their expenditures are chargeable as agency feesa complex determination because many union activities may not neatly fit into the first two categories.

\section{Agency Fees in the Public Sector}

When Congress enacted the NLRA and the LMRA, it exempted public employers such as government agencies from coverage. Early adversaries to collective bargaining in the public sector based their opposition on a belief that such allowances were in conflict with existing civil services laws or, at the very least, unnecessary due to the protections they already afforded..$^{50}$ Others opposed granting bargaining rights to public servants, believing that doing so would inevitably lead to future strikes that would endanger the public. ${ }^{51}$ Even lauded social democrat President

48 Id. at 121. The Allen Court places this burden on the union mainly for practical reasons, contending that "[s]ince the unions possess the facts and records from which the proportion of political to total union expenditures can reasonably be calculated, basic considerations of fairness compel that they, not the individual employees, bear the burden of proving such proportion." Id. at 122 .

49 Id. at 121-22. Because the record in Allen was insufficient to determine what portion of the objector employees' fees were being used to finance political activities, the Court remanded the case, instructing the lower court to determine: "(1) what expenditures disclosed by the record are political; (2) what percentage of total union expenditures are political expenditures." Id. at 121.

50 See Joel M. Douglas, State Civil Service and Collective Bargaining: Systems in Conflict, 52 PuB. Admin. ReV. 162, 163-64 (1992); David Lewin \& Raymond D. Horton, The Impact of Collective Bargaining on the Merit System in Government, 30 ARB. J. 199, 200-01 (1975).

51 See Martin H. Malin, The Paradox of Public Sector Labor Law, 84 IND. L.J. 1369, 1376 (2009) (noting that the threat of strike was behind several early court decisions against public sector employer collective bargaining, despite the union's recognition that strikes were not permissible). 
Roosevelt opposed strikes related to public sector collective bargaining, fearing chaos if employees responsible for performing public health and safety services, such as police and firefighters, ever went on strike. ${ }^{52}$ Other opponents thought that merely the fear of a public employee strike would be exploited by public employees at the bargaining table in order to win excessive economic concessions. ${ }^{53}$ Still others saw the NLRA as ripe for constitutional challenge and refrained from the public sector collective bargaining discussion until the issue was fully resolved in the private sector. $^{54}$

Sentiments changed, however, in the three decades that followed, when public sector employment increased fourfold in the United States,

52 Letter from Franklin Roosevelt, President, United States, to Luther C. Steward, President, Nat'1 Fed'n of Fed. Emps. (Aug. 16, 1937), http://www.presidency.ucsb.edu/ws/index.php?pid=15445 [https://perma.cc/FB32-BYH6]. But see Myron Lieberman, Public-SeCtor BARGaining 29 (1980) (noting that "the word 'essential' was used without qualifications" to define all public employees, and that some government services "are hardly essential to public health and safety").

53 See Russell A. Smith, State and Local Advisory Reports on Public Employment Labor Legislation: A Comparative Analysis, $67 \mathrm{MICH}$. L. REV. 891, 892-94 (1969); see also KURT L. Hanslowe, The Emerging Law of Labor Relations in Public Employment 11-20 (1967) (“To the extent that collective bargaining entails joint determination of conditions of employment, such bargaining with the government is seen as unavoidably creating an interference in the sovereign's affairs."). See generally Charles M. Rehmus, Labor Relations in the Public Sector in the United States, 109 INT'L LAB. REV. 199 (1974). Other practical considerations may have also delayed public sector unionization. Public sector employees prior to the 1960s "were not generally dissatisfied with their terms and conditions of employment and therefore, except in isolated cases, did not press for collective bargaining rights" before then. Id. at 202. Moreover, prior to the 1960s, private sector unions and their international federations were probably fully occupied in trying to increase the extent of organization in the private sector. $I d$. Only after union membership in the private sector began to decrease did these private sector international unions begin to see the large and growing number of public sector employees as a fertile alternative. Id.

54 See generally Joseph E. Slater, Public Workers: Government Employee Unions, the LAW AND THE STATE, 1900-1962 (2004). Responses to early twentieth century attempts to secure bargaining rights in the public sector suggest that a majority of the public also opposed it. In September of 1919, nine people were killed and hundreds more were injured when the city was left lawless for three days after over 70\% of Boston's police force went on strike. Joseph Slater, Labor and the Boston Police Strike of 1919, in THE ENCYCLOPEDIA OF StRIKes IN AMERICAN History 241, 246-47 (Aaron Brenner et al. eds., 2009). Before the strike, Boston police officers worked regular weeks of between seventy-three hours and ninety-eight hours and were sometimes required to remain on duty for seventeen hours straight. Id. at 246. Following the strike, Massachusetts' then-obscure governor, Calvin Coolidge, fired all 1,147 of the striking officers and denounced their behavior. Id. at 241. His hard stance was applauded by the media and Boston civilians - who collected $\$ 471,758$ to pay state guards until replacements were found-and thrust Coolidge into the political spotlight. Id. at 250. By 1923, Calvin Coolidge was the thirtieth President of the United States. Francis Russell, The Strike That Made a President, 14 AM. HeRITAGE, Oct. 1963, http://www.americanheritage.com/content/strike-madepresident [https://perma.cc/WPD8-4NNE]. Unfortunately for public sector unions, courts and officials opposing public sector unionism sometimes cited the Boston Strike as a cautionary tale through the end of the 1940s. See Joseph E. Slater, The Court Does Not Know "What a Labor Union Is": How State Structures and Judicial (Mis)constructions Deformed Public Sector Labor Law, 79 OR. L. REV. 981, 1010, 1013 (2000). 
outpacing employment growth in the private sector. ${ }^{55}$ As public employees grew in number and the NLRA's Supreme Court successes renewed confidence in the collective bargaining process, several state legislatures enacted laws granting limited bargaining rights to public employees beginning in the late 1950s. ${ }^{56}$ While most of these statutes resembled the private sector collective bargaining structure of the LMRA and adopted similar union security language, others chose to codify their more restrictive policies on union security agreements as permitted under Section 14(b) of the LMRA. ${ }^{57}$ The result was a piecemeal collection of state legislation governing collective bargaining between state and local governments and their employees.

1. The Court's Application of Private Sector Agency Fee Doctrine to the Public Sector: Abood v. Detroit Board of Education

Following its private sector decision in Allen, the Court was silent on agency fees for nearly fifteen years. During these years, significant collective bargaining rights arrived in the public sector for the first time..$^{58}$

55 See Developments in the Law-Public Employment, 97 HARV. L. REV. 1611, 1614-15 (1984).

56 See id.; see also Project, Collective Bargaining and Politics in Public Employment, 19 UCLA L. REV. 887, 893 (1972). Wisconsin enacted the first state public sector bargaining law in 1959 with Minnesota quick to follow. Developments in the Law, supra note 55, at 1678. Thirty additional states followed suit during the 1960s and 1970s. Id. at 1679. President John F. Kennedy followed the states' trend and granted bargaining rights to federal employees in 1962 by signing Executive Order 10988. Exec. Order No. 10,988, 3 C.F.R. § 521 (1962). Earlier federal legislation like the Lloyd-LaFollette Act of 1912 provided some formal protections for federal agency employees. Lloyd-LaFollette Act, ch. 389, $\S 6,37$ Stat. 555 (1912) (codified at 5 U.S.C. § 7511 (2012)). The Lloyd-LaFollette Act, for example, provided essentially a "just cause" termination requirement, but there were no significant appellate rights for a decisionmaker's just cause decision. See Veterans Preference Act, ch. 287, § 8, 58 Stat. 389 (1944) (codified at 5 U.S.C. $\S 2108$ (2012)) (providing veterans who enter into public service employment the right to challenge adverse personnel actions). It was no coincidence that Wisconsin was the first state to pass legislation granting collective bargaining rights to public employees. See Mari Jo Buhle, The Wisconsin Idea, IN IT STARTED IN WiSCONSIN: DiSPATCHES FROM THE FRONT LINES OF the New Labor Protest 14 (Mari Jo Buhle \& Paul Buhle eds., 2011); Paul Buhle \& Frank Empsak, Labor, Social Solidarity, and the Wisconsin Winter, in IT STARTED IN WISCONSIN, supra, at 101-03; Roger Bybee, The Role of Corporations, in IT STARTED IN WISCONSIN, supra, at 139. In 1932, the American Federation of State, County and Municipal Employees (AFSCME) - now the largest union of public employees in the United States - was first established as a public employee association by a small group of professional state employees in Madison, Wisconsin. Buhle \& Empsak, supra, at 101-02.

57 See HANSON ET AL., supra note 29, at 143-45.

58 See Joseph Slater, The Strangely Unsettled State of Public-Sector Labor in the Past Thirty Years, 30 HOFSTRA LAB. \& EMP. L.J. 511 (2013). In 1956, the first year for which statistics on membership in public sector unions were kept, there were 915,000 union members in the public sector. By 1978, public sector membership had grown by $296 \%$ to 3,625,000. Myron Lieberman, Teacher Bargaining: An Autopsy, 63 PHi DELTA KAPPAN 231, 232 tbl.1 (1981). 
Moreover, during this period the Court also settled important First Amendment principles relating to financial contributions. ${ }^{59}$

The Supreme Court first addressed the constitutionality of agency shop agreements in the public sector in Abood v. Detroit Board of Education. ${ }^{60}$ In Abood, a group of teachers objected to the payment of agency fees under a collective bargaining agreement entered into between the Detroit Board of Education and their union representative. ${ }^{61}$ The petitioners argued first that Hanson and Street did not apply because agency fees in the public sector, and not just those utilized for political purposes, required a different First Amendment consideration than their private sector counterparts. ${ }^{62}$ Second, they argued that even under the Hanson and Street analysis, union costs for collective bargaining cannot be charged to agency fee payers because "public sector collective bargaining itself is inherently political." ${ }_{63}$

Writing for the majority in Abood, Justice Potter Stewart began by rejecting the petitioner's First Amendment public-private distinction to employment and collective bargaining. Justice Stewart reasoned that, although there may be "very real differences" between public and private collective bargaining, these differences are related to the special character of the employer and not the employees. ${ }^{64}$ Thus, these differences "are not such as to work any greater infringement upon the First Amendment interests of public employees." ${ }^{65}$ According to Justice Stewart, "[p]ublic employees [were] not basically different from private employees; on the whole, they have the same sort of skills, the same needs, and seek the same advantages." ${ }_{66}$

With the argument for a private-public distinction disposed of, Justice Stewart then applied the agency fee analysis outlined in Hanson and Street.

59 See, e.g., Buckley v. Valeo, 424 U.S. 1 (1976).

60431 U.S. 209 (1977).

${ }^{61} I d$. at 212-13. The Detroit Federation of Teachers was certified as the exclusive representative of teachers employed by the Detroit Board of Education in 1967 following a secret ballot election. See MicH. COMP. LAWS $§ 432.211$ (1979) (extending some bargaining rights to public employees). The Court noted in Abood that "although not identical in every respect," Michigan's agency shop provisions were "broadly modeled after federal law." Abood, 431 U.S. at 223 (citing Rockwell v. Bd. of Educ., 227 N.W.2d 736, 744-45 (Mich. 1975); Mich. Emp't Relations Comm'n v. Reeths-Puffer Sch. Dist., 215 N.W.2d 672, 675 \& n.11 (Mich. 1974); Detroit Police Officers Ass'n v. City of Detroit, 214 N.W.2d 803, 807-08 (Mich. 1974)).

62 Abood, 431 U.S. at 213-14; see also Brief for Appellants at 189-96, Abood, 431 U.S. 209 (No. 75-1153), 1976 WL 181666.

63 Abood, 431 U.S. at 227 (internal quotation marks omitted).

${ }^{64} I d$. at 230.

${ }^{65} \mathrm{Id}$.

${ }^{66} I d$. at $229-30$. 
He began by adopting the same government interests supporting agency fees in the private sector to Abood, noting that "[t]he desirability of labor peace is no less important in the public sector, nor is the risk of 'free riders' any smaller." ${ }^{67}$ Justice Stewart's analysis, however, deviated from Hanson and Street as to how these interests impacted First Amendment rights. Hanson and Street recognized these government interests in deciding that agency fees used for collective bargaining purposes do not infringe upon an agency fee payer's association rights. ${ }^{68}$ In Hanson and Street, the Court found that agency fees compelled a payment in exchange for the union's collective bargaining services and likened this to other governmentcompelled fees in exchange for goods or services. ${ }^{69}$ Therefore, Hanson and Street saw no compelled association in agency fees because the required agency fee payment was not likely to result in identifying the agency fee payer with the union..$^{70}$ Abood, however, stated that compelled financial support of a union might infringe upon an individual's First Amendment association rights but that such an infringement is justified to promote government interests. ${ }^{71}$

Although the Abood Court was unclear as to its reasons behind adopting this alternative, its reliance on Buckley v. Valeo is instructive. ${ }^{72}$ Decided just one year prior to Abood, Buckley dealt with the constitutional validity of a federal law limiting campaign contributions. ${ }^{73}$ After a complicated and lengthy analysis, Buckley held that limiting contributions "inpinge[s] on protected associational freedoms." " The Abood Courtreasoning that compelling contributions is no less of an infringement than restricting them-cited Buckley for its proposition that "contributing to an organization for the purpose of spreading a political message is protected by the First Amendment." 75 Thus, Abood may have attempted to reconcile Buckley's somewhat "incomprehensible" analysis and new holding that

67 Id. at 224.

68 See Int'l Ass'n of Machinists v. Street, 367 U.S. 740, 770 (1961); Ry. Emps.' Dep't v. Hanson, 351 U.S. 225, 238 (1956).

69 See Street, 367 U.S. at 768; Hanson, 351 U.S. at 238; see also supra Section I.B.

70 Street, 367 U.S. at 767-68; Hanson, 351 U.S. at 236-38.

71 Abood, 431 U.S. at 226-27 (1977) (reasoning that requiring a public employee to subsidize collective bargaining "might well be thought . . . to interfere in some way with an employee's freedom to associate for the advancement of ideas, or to refrain from doing so").

72 See id. at 234 (quoting Buckley v. Valeo, 424 U.S. 1, 22 (1976) (per curiam)).

73 Buckley, 424 U.S. at 1.

74 Id. at 22; see also JefFrey ToOBIn, The OAth: The OBAma White House AND the Supreme COURT 149 (2012) (contending that Buckley v. Valeo "has gone down in history as one of the Supreme Court's most complicated, contradictory, incomprehensible (and longest) opinions").

75 Abood, 431 U.S. at 234. 
contributions implicate the First Amendment with the settled agency fee precedent of Hanson and Street. ${ }^{76}$

After upholding the initial validity of agency fees in the public sector context, Abood then went on to consider their validity when used to promote political or ideological activities. ${ }^{77}$ Relying heavily on its analysis in Hanson and Street, the Court unanimously held that the First Amendment prohibits the Government from "requiring any [objecting nonmember] to contribute to the support of an ideological cause he may oppose." 78

Indeed, after Abood, agency fee doctrine in the public and private sector had drawn the same bright line and reached parallel compromises but through different routes. ${ }^{79}$ Union activities germane to collective bargaining were chargeable to objecting agency fee payers, and political activities were not. The only relevant distinction a majority of the Court acknowledged between public and private sector unions in Abood was that the line between political activities and activities germane to collective bargaining "may be somewhat hazier" in the public sector. ${ }^{80}$ However, the Abood Court declined to elaborate further as to which specific hazy union activities could be financed with an objector's agency fees. ${ }^{81}$

\section{Criticisms of Abood}

Scholars have been writing on Abood's shortcomings since it was decided, but for this Article, two lines of criticism are particularly relevant. First, some commentators criticize Abood's failure to distinguish between public and private sector collective bargaining before deviating from the private sector agency fee precedent articulated in Hanson and Street. ${ }^{82}$ Although Justices John Paul Stevens, William Rehnquist, and Lewis Powell all wrote separately in Abood, only Justice Powell saw the public sector and private sector union distinction as "fundamental," noting that unlike their private sector counterparts:

76 See infra Part III.

77431 U.S. at $232-37$

$78 I d$. at 235.

79 Estlund, supra note 6, at 184.

${ }^{80}$ Abood, 431 U.S. at 236.

$81 \mathrm{Id}$.

82 See, e.g., Andrew Buttaro, Stalemate at the Supreme Court: Friedrichs v. California Teachers Association, Public Unions, and Free Speech, 20 TEX. Rev. L. \& POL. 341, 346-47 (2016). For a discussion of the differences between public and private sector collective bargaining generally, see, for example, HARRY H. WeLlington \& RALPH K WinTER, JR., THE Unions AND THE Cities 22 (1971); Clyde Summers, Bargaining in the Government's Business: Principles and Politics, 18 U. TOL. L. Rev. 265, 265 (1987); Clyde W. Summers, Public Employee Bargaining: A Political Perspective, 83 YALE L.J. 1156, 1157 (1974). 
[P]ublic-sector union activities - including collective bargaining - have an inherently political cast. Indeed, a public-sector union functions much like a political party, as the ultimate objective of both "is to influence public decisionmaking in accordance with the views and perceived interests of its membership." 83

Although enlightened in his recognition of how collective bargaining activities could inherit a political tone in the public sector, Justice Powell and his accompanying intellectuals' casting of all public sector collective bargaining activities as inherently political is as shortsighted as Abood's majority opinion. The true nature of collective bargaining activities in the public sector is that they are transient and context specific, which is why only a case-by-case balancing properly evaluates their activities and supporting agency fee payments. ${ }^{84}$

A second line of criticism maintains that Abood's interpretation of all agency fees as constitutional infringements is incomplete without a proper scrutiny of the state's interests. ${ }^{85}$ If laws permitting agency fees infringe on a payer's association rights, First Amendment jurisprudence requires that a court only sustain that action's constitutionality if it can say, subject to "exacting scrutiny," that the state has shown a compelling interest in imposing the fee. ${ }^{86}$ Furthermore, the action must be narrowly tailored so that the infringement is no greater than that which is necessary to advance the state's compelling interest. ${ }^{87}$

Justice Stewart did not subject the agency fee to this type of analysis in Abood. ${ }^{88}$ Instead Justice Stewart, limited by the lack of a developed record on which to scrutinize the Detroit Board of Education's claims and narrowly tailor the agency fees, simply deferred to the Michigan legislature's judgment that the agency shop provision promotes stable labor relations by preventing employees who are not union members from enjoying the benefits of collective bargaining without contributing to the costs of representation. Even assuming that the State's interests were compelling, Justice Stewart did not scrutinize the relationship between that

\footnotetext{
83 Buttaro, supra note 82, at 348 (quoting Abood, 431 U.S. at 250 (Powell, J., concurring)).

${ }^{84}$ See infra Section II(B) \& Section II(C).

${ }^{85}$ See Malin, supra note 10 , at 859 .

86 See Buckley, 424 U.S. at 64; see also, e.g., Roberts v. U.S. Jaycees, 468 U.S. 609, 623 (1984); NAACP v. Alabama, 357 U.S. 449, 463 (1958).

${ }^{87} \mathrm{Id}$.

${ }^{88}$ See generally Abood, 431 U.S. 209. Indeed, strangely, up until recently, no one on the Court had tried to articulate the standard of review in agency fee cases.
} 
interest and the agency shop provisions, and his efforts to tailor the agency fees are nonexistent. ${ }^{89}$

\section{Hudson and Beyond: Making Abood Work in the Public Sector}

Several years after Abood, the Court articulated a practical addition to Abood's public sector analysis in Chicago Teachers Union, Local No. 1 v. Hudson. ${ }^{90}$ In Hudson, the Court held that a public sector "[u]nion should not be permitted to exact a service fee from nonmembers without first establishing a procedure which will avoid the risk that their funds will be used, even temporarily, to finance ideological activities unrelated to collective bargaining." "These "Hudson procedures" require public sector unions to provide annual "Hudson notices" to nonmembers, notifying them of their right to object to paying fees for nonchargeable expenses..$^{92}$ The Court also required that Hudson notices provide nonmembers with "an adequate explanation of the basis for the fee, a reasonably prompt opportunity to challenge the amount of the fee before an impartial decisionmaker, and an escrow for the amounts reasonably in dispute while such challenges are pending." ${ }^{3}$ In other words, Hudson held that the procedural ability of nonmembers to review union expenditures and "opt out" of paying nonchargeable expenses was constitutionally required under the First Amendment.

Five years later, in Lehnert v. Ferris Faculty Ass'n, the Court addressed one of the "somewhat hazier" union activities Abood alluded to and held that a union could not charge objecting employees for lobbying expenses. ${ }^{94}$ Both the Hudson and Lehnert Courts, however, wholeheartedly adopted Abood's fundamental holding that agency fees were permissible in the public sector context. Justice Scalia's concurring and dissenting opinion in Lehnert is noteworthy, however. In it, he appears to adopt a First Amendment analysis and a level of scrutiny similar to the standard this Article advocates: permitting agency fee payments only to the extent that they are reasonably necessary to perform the state-mandated duties of an

\footnotetext{
89 Although Justice Stewart's failure to scrutinize the contribution of the agency shop to stable labor relations might be explained by the procedural posture of the case, he could have at least directed the lower court on remand to develop a record on which to scrutinize the state's claims and narrowly tailor the agency fees. See Malin, supra note 10, at 860-61.

90475 U.S. 292 (1986).

91 Id. at 305 (quoting Abood, 431 U.S. at 244 (Stevens, J., concurring)).

92 See id. at 310.

93 Id.

94500 U.S. 507, 518 (1991) (quoting Abood, 431 U.S. at 236); see also id. at 524 ("The union surely may not, for example, charge objecting employees for a direct donation or interest-free loan to an unrelated bargaining unit for the purpose of promoting employee rights or unionism generally.”).
} 
exclusive representative; in other words, to act on the compelling state interest using the tools the government has designated within the statute. ${ }^{95}$

\section{The Court's Move Away from Abood: Not on Its "[T]op-[T]en} [L] ist of [F] avorite [P]recedents" ${ }^{16}$

While Hudson and Lehnert represent decades where the Court applied Abood as controlling precedent, two more recent cases involving agency fees demonstrate the Court's present inclination to question Abood's First Amendment analysis and holding. ${ }^{97}$ In 2012, the Court in Knox v. Service Employees International Union, Local 1000 held that a union must send a new Hudson notice to represented employees if, during the year, union dues for members and the proportionate agency fee assessment for nonmembers changes due to additional political expenses that were not disclosed in the original notice. ${ }^{98}$

Knox involved a California union that had increased its union dues by $25 \%$ in order to defeat unanticipated ballot measures during a special election after Hudson notices were sent and the objection period had passed. ${ }^{99}$ While holding that the union violated the First Amendment by not sending a new Hudson notice, Justice Samuel Alito first reaffirmed that

95 See id. at 558-59, 562 (Scalia, J., concurring in the judgment in part and dissenting in part).

96 Harris v. Quinn, 134 S. Ct. 2618, 2652-53 (2014) (Kagan, J., dissenting).

97 See infra Part III. The Court's inclination reflects the notable doctrinal changes to the First Amendment that have occurred over the past two decades. See, e.g., Citizens United v. FEC, 558 U.S. 310, 371-72 (2010) (reasoning that because political spending is a form of protected speech under the First Amendment, the government may not limit individuals from spending as much money as they want on political elections); Riley v. Nat'l Fed'n of the Blind, 487 U.S. 781, 797 (1988) (explaining the First Amendment's freedom of speech to include a complementary freedom not to speak). For an argument that the contemporary Court's rethinking of free speech is best understood as a reaction to the Burger Court's retrenchment from the expansive conception of free speech embraced by the Warren Court, see generally Keith Werhan, The Liberalization of Freedom of Speech on a Conservative Court, 80 IOWA L. REV. 51 (1994).

98567 U.S. 298, 322 (2012). Knox followed a political shift in California, after longtime Governor Gray Davis was replaced with Arnold Schwarzenegger in 2003. Schwarzenegger's fiscal reforms included ballot measures that required teachers to work longer before tenure eligibility and restricted political spending by public employee unions. See Steven Malanga, The Beholden State: How PublicSector Unions Broke California, CITY J. 18 (Spring 2010), https://www.city-journal.org/html/beholdenstate-13274.html [https://perma.cc/V4JK-GLQP]; see also BRIAN P. JANISKEE \& KEN MASUGI, Democracy in CALIfornia: Politics AND Government IN THE Golden STATE 93 (2nd ed. 2008). The SEIU's increased agency fees went to combating the objectionable ballot measures. The SEIU spent $\$ 20$ million campaigning against the measures, with the California Teachers Association (CTA) contributing an additional $\$ 53$ million. Mark Brenner, California Nurses Lead the Fight Against Arnold Schwarzenegger's Anti-Union Ballot Measures, LAB. NOTES (Feb. 18, 2006), $\mathrm{http}: / / \mathrm{www}$.labornotes.org/2006/02/california-nurses-lead-fight-against-arnold-schwarzeneggers-antihttps://www.facebook.com/messages/t/24607605union-ballot-measures [https://perma.cc/GA4LBLTQ]. Schwarzenegger's four ballot initiatives lost overwhelmingly. See JANISKEE \& MASUGI, supra, at 93 .

99567 U.S. at 304. 
agency fees represent a "significant impingement on First Amendment rights." 100 Although he declined to revisit the propriety of this infringement in Knox, Justice Alito did go on to express the belief that some public sector collective bargaining is political. In doing so, he noted that: "a public-sector union takes many positions during collective bargaining that have powerful political and civic consequences," positions with which nonmembers may disagree. ${ }^{101}$ The Knox decision went on to explicitly rebuke the Abood Court's assumption without any "focused analysis" that public and private sector agency shop agreements are the same ${ }^{102}$ and to question the free-rider justification, calling it "generally insufficient to overcome First Amendment objections," and "something of an anomaly."103

The Court admonished Abood even further two years later in Harris $v$. Quinn. In Harris, the Court held that home healthcare professionals, jointly employed by both the State of Illinois and individuals, were not required to pay agency fees. ${ }^{104}$ Justice Alito again asserted that Abood wrongly applied the private sector agency shop analysis to the public sector, noting that "[t]he Abood Court seriously erred in treating Hanson and Street as having all but decided the constitutionality of compulsory payments to a publicsector union." 105 According to Justice Alito:

Abood failed to appreciate the difference between the core union speech involuntarily subsidized by dissenting public-sector employees and the core union speech involuntarily funded by their counterparts in the private sector. In the public sector, core issues such as wages, pensions, and benefits are important political issues, but that is generally not so in the private sector. In the years since Abood, as state and local expenditures on employee wages and benefits have mushroomed, the importance of the difference between bargaining in the public and private sectors has been driven home. ${ }^{106}$

Unimpressed by Abood's holding and "questionable foundations," the Harris Court refused to expand Abood to home healthcare workers who were not full-fledged government employees. ${ }^{107}$ However, by distinguishing home healthcare workers as beyond Abood's purview, the

\footnotetext{
100 Id. at 310-11 (quoting Ellis v. Bhd. of Ry., Airline \& S.S. Clerks, 466 U.S. 435, 455 (1984)).

101 Id. at 310 (citation omitted).

102 Id. at 313.

103 Id.

104134 S. Ct. 2618, 2644-45 (2014).

105 Id. at 2632.

106 Id.

107 Id. at 2638.
} 
Court avoided the petitioners' request to expressly overrule it. ${ }^{108}$ Justices Elena Kagan, Ruth Bader Ginsburg, Stephen Breyer, and Sonia Sotomayor dissented from the majority's "potshots at Abood" in Harris. ${ }^{109}$ Justice Kagan vigorously defended the precedent, writing that "[f]or some 40 years, Abood has struck a stable balance-consistent with this Court's general framework for assessing public employees' First Amendment claims - between those employees' rights and government entities' interests in managing their workforces." 110 In spite of her efforts, the majority's intentions appeared inevitable. Although Abood had been reluctantly pardoned by the Court, after Harris it survived only on death row.

Recognizing their close proximity to victory, opponents to agency fees quickly brought another case in 2015, but with the Court shorthanded after the death of Justice Scalia, Friedrichs v. California Teachers' Ass' $n$ resulted in a 4-4 per curiam decision. ${ }^{111}$ Undeterred, and hoping the Court would again take up the issue when restored to its full complement of Justices, agency fee opponents immediately began funding subsequent cases in the lower courts. ${ }^{112}$ In April 2017, Justice Gorsuch succeeded Justice Scalia, ${ }^{113}$ and five months later, the Supreme Court agreed to hear Janus v. AFSCME — its fourth agency fee case in five years. ${ }^{114}$

108 Id. at 2638 n.19. But see id. at 2645 (Kagan, J., dissenting) (noting that the Court's refusal to overrule Abood is "cause for satisfaction, though hardly applause").

109 Id. at 2645 (Kagan, J., dissenting).

${ }^{110} \mathrm{Id}$. at 2658. Moreover, her dissent sniffed out the right-wing political objective behind the majority's opinion in Harris and the circumstances surrounding it:

For many decades, Americans have debated the pros and cons of right-to-work laws and fairshare requirements. All across the country and continuing to the present day, citizens have engaged in passionate argument about the issue and have made disparate policy choices. The petitioners in this case asked this Court to end that discussion for the entire public sector, by overruling Abood and thus imposing a right-to-work regime for all government employees. The good news out of this case is clear: The majority declined that radical request. The Court did not, as the petitioners wanted, deprive every state and local government, in the management of their employees and programs, of the tool that many have thought necessary and appropriate to make collective bargaining work.

Id.

111136 S. Ct. 1083 (2016) (per curiam).

112 See Moshe Z. Marvit, Labor Opponents Already Have the Next 'Friedrichs' SCOTUS Case Ready to Go Under Trump, IN THESE TIMES, Jan. 4, 2017, available at $\mathrm{http}: / /$ inthesetimes.com/working/en

Try/19776/will_trumps_supreme_court_reverse_fair_share_fees_unions_foes_hope_so [https://perma.cc/2VY3-69LF].

113 Id.

${ }^{114}$ Id. 
N ORTHW ESTER N UNIVERS ITY L A W RE VIE W

\section{Nonjudicial Changes to Public Unions AND Collective BARGAINING IN THE YEARS SINCE $A B O O D$}

Abood arrived at the Supreme Court when public sector labor statutes and collective bargaining were still in their infancy. ${ }^{115}$ Once a state enacted collective bargaining legislation, public sector employee associations were usually absorbed into existing private sector labor unions. ${ }^{116}$ A powerful force in the 1950s economy, these unions came to see the growing number of public employees as the solution to their steady private membership decline and aggressively sought to represent public sector employees. ${ }^{117}$

\footnotetext{
115 See Labor Management Relations Act, Pub. L. 80-101, 61 Stat. 136 (1947) (codified in scattered sections of 29 U.S.C. (2012)).

116 See Richard W. Hurd \& Sharon Pinnock, Public Sector Unions: Will They Thrive or Struggle to Survive?, 25 J. LAB. RES. 211, 214-20 (2004). While most public sector employees were absorbed into existing unions, a few professional associations from the public sector successfully evolved into union representatives and have remained independent. The National Education Association (NEA) and the Fraternal Order of Police are the most prominent examples of professional associations that adopted union tactics and collective bargaining in order to retain their independent status. AFSCME and SEIU were the two most successful unions at absorbing past professional associations in the public sector. Largely because of their success in absorbing smaller associations, AFSCME and SEIU were also the two fastest growing unions during the 1970s and 1980s. See Leo Troy, Are Municipal Collective Bargaining and Municipal Governance Compatible?, 5 U. PA. J. LAB. \& EMP. L. 453, 482 (2003). Teamsters and the Communication Workers of America were also able to absorb some professional associations but with less success. See City of Escanaba v. Mich. Labor Mediation Bd., 172 N.W.2d 836, 841 (Mich. Ct. App. 1969); State ex rel. Missey v. Cabool, 441 S.W.2d 35, 42 (Mo. 1969) (holding that without a statutory provision to the contrary, public employees may join unions affiliated with national union organizations or unions that have private employees as members); Levasseur v. Wheeldon, 112 N.W.2d 894, 898 (S.D. 1962).

117 See Donald H. Wollett et Al., Collective Bargaining IN Public Employment 7 (4th ed. 1993). After the American Federation of Teachers (AFT) became affiliated with the United Autoworkers (UAW) and the AFL-CIO, the groups began an aggressive initiative in 1961 to win the representative status of public school teachers in major cities. Despite the NEA having more professional members, the resources and organizational activities of the AFT and its traditionally private union affiliates proved immensely successful because the AFT beat out the NEA for representational rights in the New York, Chicago, Baltimore, District of Columbia, Philadelphia, and Boston city school systems. $I d$. at 7-8.
} 


\section{A. The Early Differences Between Private and Public Employment and Collective Bargaining: "[A] [V]ery [F]at [M]an [S]tuffed into a [L]ittle Lord Fauntleroy [S] uit"'118}

The successful incorporation of public sector employees into the traditionally private union model relied on the perception that public employees were in fact not discernible from their private counterparts. ${ }^{119}$ And in a broad employment sense this was true, in that both public and private employees were concerned with fair wages and benefits, recognition, the redress of wrongs, and decent working conditions. ${ }^{120}$ Because of these similarities, union leaders argued that the private sector model of collective bargaining - which involved good faith negotiations of wages and working conditions, a mutually binding contract for a specific duration, exclusive representation, and an agreement to share responsibility for administering the provisions of that contract-was also the most effective means of handling labor relations in the public sector. ${ }^{121}$ There were, however, important differences between the two as they related to public policy, leverage during negotiations, and individual guarantees of the Due Process Clause and the First Amendment. ${ }^{122}$

First, the principal goals of government employees were politically determined, as opposed to private sector objectives that were economically driven. ${ }^{123}$ These politically determined goals, like politics itself, tended to

\footnotetext{
118 Herbert L. Haber, Proceedings of a Conference Held By The Institute OF MANAGEMENT \& LABOR RELATIONS 7-10 (1968) (discussing the relevance of private sector experience to public sector bargaining). Herbert L. Haber was City Director of Labor Relations, New York, New York, from 1966-1973. During a conference held by the Institute of Management and Labor Relations in 1968, Haber made this early observation when explaining the many differences between the private and public sectors of employment and why such differences meant that the rules for collective bargaining in the private sector could not be simply draped over the public sector without "extensive tailoring." Id. at 10. To simply try and do so "recalls the cartoons I'm sure all of you have seen of the little boy wearing his daddy's coat, or of a very fat man stuffed into a little Lord Fauntleroy suit." Id.

The author has tried and failed to locate any of these illustrious cartoons and fears they may have been lost to time.

119 Id. at $7-10$

120 Id. at 8 .

121 See Jungin Kim, The Role of Public-Sector Unions During Privatization, 25 KoreAn J. PoL'Y STUD. 23, 26 (2010).

122 See Local Distress, State Surpluses, Proposition 13: Prelude to Fiscal Crisis or New Opportunities?: Hearing Before the Subcomm. on the City of the H. Comm. on Banking, Finance and Urban Affairs, 95th Cong. 397-98 (1978) [hereinafter Fosler] (statement of R. Scott Fosler, Director, Government Studies of the Committee for Economic Development); see also Connick v. Myers, 461 U.S. 138, 149-52 (1983); Staughton Lynd, Employee Speech in the Private and Public Workplace: Two Doctrines or One, 1 BeRKeley J. EMP. \& LAB. L. 711 (1977). See generally Gerald E. Frug, Does the Constitution Prevent the Discharge of Civil Service Employees?, 124 U. PA. L. REV. 942 (1976) (discussing the due process requirements for public employees).

123 See Fosler, supra note 122, at 400; see also THOM REILly, RETHINKING PUBLIC SECTOR COMPENSATION: WhAT EVER HAPPENED TO THE PUBLIC INTEREST? 68 (2012).
} 
be more numerous and intangible than goals in private business. ${ }^{124}$ Moreover, because employees in the public sector were not concerned with competition or profits, few market constraints limited their demands. ${ }^{125}$ Mandatory taxes funded government operations, so the government did not need to hold the price of its operations down to attract customers. ${ }^{126}$

Another important distinction between the public and private employment sector related to the hierarchal structure and authority within employment. ${ }^{127}$ Employees in the public sector actively participated in the selection of their employers, the elected officials, whereas private sector unions did not. Moreover, a distinct authoritative structure in the private sector made it easier to identify who was on the other side of the bargaining table. In the private sector, the union actively bargained against private business owners, the interests of shareholders, and management, whereas in the public sector, bargaining sides were more obscure. Elected officials did not profit from favorable concessions, and ultimately the interests of taxpayers (some of whom were also public employees and union members) were impacted by the results. ${ }^{128}$ Furthermore, scholars early on recognized the potential "two bites at the apple" advantage exclusive to public sector bargaining employees, where unions could attempt by lobbying to secure from elected officials and the legislature that which they failed to obtain at the bargaining table. ${ }^{129}$

\footnotetext{
124 Fosler, supra note 122 , at 400.

125 See ReILly, supra note 123, at 68 (noting that private sector unions know to mitigate their demands, or not to "give away the farm" because their employers could go out of business; public unions have no such incentive because their industry is not driven by market discipline); see also Harry C. Katz et al., Crisis and Recovery in the U.S. Auto Industry: Tumultuous Times for a Collective Bargaining Pacesetter, in Collective Bargaining Under Duress : CaSe Studies of Major U.S. INDUSTRIES 46, 75-77 (Howard R. Stranger et al. eds., 2013). The UAW, a private union known historically as a highly centralized and militant organization that had successfully negotiated generous benefits in the past, agreed to large concessions in 2007 and even more in 2009 during the General Motors and Chrysler bankruptcies to help the companies stay afloat. James Sherk, How Collective Bargaining Affects Government Compensation and Total Spending, HeRITAGE FounD. (Apr. 22, 2015), http://www.heritage.org/testimony/how-collective-bargaining-affects-government-compensation-andtotal-spending [https://perma.cc/MVD8-5N3A].

126 See Fosler, supra note 122, at 401. The states' monopolies on essential services give government unions "tremendous leverage to force concessions." REILLY, supra note 123, at 68.

127 See Fosler, supra note 122, at 401.

128 Id.; see also ReILly, supra note 123, at 68 .

129 See HABER, supra note 118, at 9-10. This concept is also referred to in scholarship as "“end run' or 'double-deck' bargaining." Id. at 9; see also Michael H. Gottesman, Wellington's Labors, 45 N.Y. L. SCH. L. REV. 77, 81 (2001). The concern that public labor unions would take "two bites at the apple" were valid. At the state level especially, public labor unions have successfully used their political lobby to influence public sector employment legislation. Up until quite recently, politicians that refused their demands often faced tough reelection campaigns and union opposition. See, e.g., Patrice M. Mareschal, Innovation and Adaptation: Contrasting Efforts to Organize Home Care Workers
} 
Public and private sector union members also differed in the Due Process Clause rights and applicable civil service laws they had in the workplace without collective bargaining. Whereas private sector employees could be terminated "at will" without an appeal and were presumed to have no rights to continued employment without a collective bargaining agreement stating differently, due process required minimum procedural protections from sudden terminations in the public sector. Far beyond these minimal due process protections, state and federal civil services laws also protected public sector employees from both arbitrary and partisan terminations.

\section{B. The Internal Evolution: Public Sector Unions and "Professional Unionism"}

The number of government employees exploded during the decades that followed the first public sector labor laws. ${ }^{130}$ With this unprecedented growth, public sector unions and collective bargaining also grew in size and acceptance, with a majority of states adopting collective bargaining laws by the end of the 1970s and public sector union density peaking at just over $38 \%{ }^{131}$ The workable alternatives to strikes at impasse-mainly mediation and fact-finding - had cultivated a stabilizing image of public sector bargaining and for the most part proven its opponents wrong. ${ }^{132}$ However, as the public employment sector grew, differences between these new public sector union members, the union members of old, and the representative models able to effectively aid the two became more apparent. ${ }^{133}$

The influx of public sector employees caused a dramatic change in union membership demographics. Unlike the prototypical private union members from the 1950s who were "blue-collar" industrial working white

\footnotetext{
in Four States, 31 LAB. STUD. 25, 32-33 (2006) (noting that in 2000, SEIU Local 503 was instrumental in getting Oregon to pass legislation that created a home-care commission to set the standards for inhome caregivers and serve as their employer of record). Unions have also lobbied governors to gain rights that were not gained at the bargaining table. The efficiency of this design is that it is cheaper and easier to convince one person to pass an executive order than persuade the majorities in both houses of the legislature to pass similar legislation. See, e.g., 14 Ariz. Admin. Reg. 4945, 4947-49 (Dec. 26, 2008) (Governor Janet Napolitano awarding public state employees "meet and confer" rights).

130 See Tom Juravich \& Kate Bronfenbrenner, Preparing for the Worst: Organizing and Staying Organized in the Public Sector, in Organizing to Win: NeW ReSEARCh On UNION STRATEGIES 262 (Kate Bronfenbrenner et al. eds., 1998) (noting that the number of government employees went from 7.8 million in 1958 to more than 15.7 million in 1978).

131 See id. (public sector union density jumping from $10.6 \%$ in 1958 , to $38.2 \%$ in 1977 ); see also Slater, supra note 58, at 518-19.

132 See Slater, supra note 58 , at $517-18$.

133 See HABER, supra note 118, at 9 .
} 
males clad in "hard hats" and "steel-toed boots," a substantial number of public sector union members were "professional" or "white collar" employees. ${ }^{134}$ On average, these public sector professional employees had more years of education, were more likely to be female, and reported a stronger personal attachment to their jobs and occupational identity than conventional private sector union members. ${ }^{135}$ Moreover, the employment values of these professional employees varied significantly from just the traditional "bread and butter" terms and conditions of employment that dominated private sector collectively-bargained-for contracts. ${ }^{136}$ Many of these professional employees - by virtue of their expertise and intellectual training - desired participation in organizational policy and a voice in setting professional standards even more than a say in the traditional terms and conditions of employment. ${ }^{137}$ Thus, after obtaining organizing rights, they soon rejected the early public sector unions patterned after the private sector model, which viewed labor and management interests as conflicting

134 See Herbert B. Asher et Al., American Labor Unions In the EleCtoral Arena 28, 35 (2001). Although more than $81 \%$ of union members were blue collar in 1952, white collar professional workers gained majority status among union members in 1996. By 2015, women made up 46\% of union membership, despite members being overwhelmingly male in 1952 (85\% male), and African Americans and Hispanics now make up a noticeable portion of the union population that was once predominately white. Table 1: Union Affiliation of Employed Wage and Salary Workers by Selected Characteristics, U.S. BUREAU OF LAB. STAT. (Jan. 26, 2017), https://bls.gov/news.release/union2.t01.htm [https://perma.cc/B5UD-7FKQ]. See also 29 U.S.C. $\S 152(11)-(12)$ (2012); 29 U.S.C. $§ 157$ (2012). Because many professional employees are also supervisors, the exclusion of professionals from private union membership stems in large part from the Taft-Hartley amendment excluding "supervisors" from coverage under the NLRA. The Taft-Hartley amendment, however, does allow nonsupervisor "professional employee[s]" to self-organize and bargain collectively through representatives, and although still low, the rate of unionized professional employees in the private sector is slowly increasing. See Gerald Mayer, Cong. Research SERV. UNION MEMBERSHIP TRENDS IN THE UNITED STATES 16 (2004), http://digitalcommons.ilr.cornell.edu/ key_workplace/174 [https://perma.cc/954X-JH3D].

135 See MAYER, supra note 134; see also GERAld MAYER, Cong. RESEARCh SERV., SELECTED Characteristics of Private AND Public SECTOR WORKers (2011), http:/govexec.com/pdfs/ 071911kl1.pdf [https://perma.cc/89DJ-ULSJ]. The trend of public employees who are union members being generally more educated than their private sector union membership continues. In 2003, almost three-fourths $(73.6 \%)$ of union members with a bachelor's or advanced degree were employed in the public sector. See Richard W. Hurd \& John Bunge, Unionization of Professional and Technical Workers: The Labor Market and Institutional Transformation, in EMERGING LABOR MARKET INSTITUTIONS FOR THE TWENTY-FIRST CENTURY 178, 186 (Richard Freeman et al. eds., 2005).

136 David M. Rabban, Can American Labor Law Accommodate Collective Bargaining By Professional Employees?, 99 YALE L.J. 689, 691 (1990). Collective bargaining agreements are legally enforceable contracts that span the course of several years and form the bedrock of the continuing employment relationship between labor and management.

137 See id.; see also Hurd \& Bunge, supra note 135, at 186 (empirical findings show that those professionals who choose to engage in "group activity" are most interested in representational preferences for professionals, showing that more than wages and benefits, professional employees are concerned with having a voice in organizational policies and preserving freedom to exercise professional judgment). 
and the bargaining scope of contractual agreements as restrictive. ${ }^{138}$ Instead, they pushed for representatives who would negotiate collaborative roles in professional management and policymaking, ${ }^{139}$ following a "professional unionism" representative model. ${ }^{140}$

Even for unions open to this new professional unionism representative model, the applicable public sector statutes presented a challenge because they had been fashioned after federal labor law in the private sector, which was not particularly amenable to employee roles in organizational policy. ${ }^{141}$ Federal labor law distinguishes between "mandatory" subjects of bargaining (the "bread and butter" wage, hours, and conditions of employment issues) from those subjects that are merely "permissive" bargaining subjects (all other legal bargaining subjects, including those related to organizational policy). ${ }^{142}$ The assumption that management and labor representatives' interests are inherently adversarial has, in the past, made employers in the private sector reluctant to even discuss permissive

138 See Randall W. Eberts, Teachers Unions and Student Performance: Help or Hindrance?, 17 Future ChILD. 175, 179 (2007) (explaining professional unions' desires to move from an adversarial model to a more collaborative collective bargaining one where professionals and government decisionmakers share common goals and hold joint responsibility); see also Charles Taylor Kerchner \& Julia E. Koppich, Negotiating What Matters Most: Collective Bargaining and Student Achievement, 113 AM. J. ED. 349, 351-52 (2007) (describing how teachers unions worked their way out of narrowly constructed bargaining structures to include topics such as professional development and educational standards in collective bargaining).

139 Some representatives needed less pushing to seek this kind of influence, having their roots as professional associations prior to the public sector labor movement anyway. See Sar A. Levitan \& Frank Gallo, Can Employee Associations Negotiate New Growth?, 112 Monthly LaB. ReV. 5, 5 (1989). Note, however, that many professional employees rejected the idea of unionization, believing that the principles of collective bargaining were not compatible to the professional values of collegiality, autonomy, and individual responsibility. See Henry Mintzberg, A Note on the Unionization of Professionals from the Perspective of Organization Theory, 5 INDUS. REL. L.J. 623, 630-34 (1983); see also Sanford H. Kadish et al., The Manifest Unwisdom of the AAUP as a Collective Bargaining Agency: A Dissenting View, 58 AAUP BulL. 46, 57-61 (1972) (three dissenting members of the governing Council of the American Association of University Professors (AAUP) authoring a statement staunchly opposed to the AAUP's recent vote to "pursue collective bargaining as a major additional way of realizing the Association's goals in higher education").

140 See Kerchner \& Koppich, supra note 138, at 351-52 (describing Albert Shanker's use of the term "professional unionism" in the mid-1980s during a speech to AFT leaders as the turning point in public sector union initiatives)

141 See Rabban, supra note 135, at 692-93.

142 Id. at 702-04; see also NLRB v. Wooster Div. of Borg-Warner Corp., 356 U.S. 342, 349-50 (1958) (bargaining proposal which "settles no term or condition of employment" does not concern a mandatory subject of bargaining); Silverman v. Major League Baseball Player Rel. Comm., Inc., $880 \mathrm{~F}$. Supp. 246 (S.D.N.Y. 1995), aff'd, 67 F.3d 1054 (2d Cir. 1995) (mandatory subjects of bargaining encompass wages, hours, and other terms and conditions of employment; permissive subjects of bargaining are all other matters). 
bargaining subjects in the interests of preserving management discretion to the utmost extent. ${ }^{143}$

Public sector unions, however, have proved immensely successful in bargaining over these permissive subjects, particularly as they relate to collaborative policy roles for their professional employees. ${ }^{144}$ Teachers unions have been at the forefront of this, negotiating provisions in collective bargaining agreements related to the length of school days, student-teacher ratios, instructional and preparation time, the use of performance indicators, school safety provisions, and professional qualifications for hire. ${ }^{145}$ But teachers are not the only professionals to negotiate organizational decisionmaking roles in the public sector. Public defenders and legal aid attorneys have also negotiated reduced caseloads and adequate space to counsel their clients in privacy. ${ }^{146}$ Nurses in public health institutions have used collective bargaining to maintain adequate nurse-patient ratios and staffing provisions. ${ }^{147}$ And police unions have

143 See Kenneth G. Dau-Schmidt, Promoting Employee Voice in the American Economy: A Call for Comprehensive Reform, 94 MARQ. L. REV. 765, 769-71 (2011). For judicial discussions of well-drafted "management rights" clauses in collectively bargained for contracts, wherein a union and employer unmistakably acknowledge a certain issue as a permissive subject of bargaining and waive their right to bargaining over a particular issue, see Laurel Baye Healthcare of Lake Lanier, LLC and United Food and Commercial Workers Union, Local 1996, 352 N.L.R.B. 179 (2008), review granted, decision vacated on other grounds sub nom. Laurel Baye Healthcare of Lake Lanier, Inc. v. NLRB, 564 F.3d 469 (D.C. Cir. 2009)

144 See Paul T. Hill, The Costs of Collective Bargaining Agreements and Related District Policies, in Collective Bargaining in EdUCATion 89, 91-92 (Jane Hannaway \& Andrew J. Rotherham eds., 2006) (describing the success teachers' unions had in shaping school policy through the collective bargaining process and permissive bargaining topics).

145 See Saul A. Rubinstein \& John E. McCarthy, Collaborating on School Reform: Creating Union-Management Partnerships to Improve Public School Systems 3-5 (2010); JONATHAN ECKERT ET AL., U.S. DEP'T OF EDUC., LOCAL LABOR MANAGEMENT RELATIONSHIPS AS A Vehicle to AdVANCE REFORM 4 (2011) (describing case studies in which labor-management partnerships have contributed to improved student outcomes in a range of areas by facilitating "teacher leadership," which is "essential to dynamic decision-making").

146 See Laura Midwood \& Amy Vitacco, Note, The Right of Attorneys to Unionize, Collectively Bargain, and Strike: Legal and Ethical Considerations, 18 HOFSTRA LAB. \& EMP. L.J. 299, 308-11 (2000); see also Lesley Oelsner, 400 Legal Aid Lawyers Go on Strike for Better Pact, N.Y. TiMES, July 3, 1973, at 1; Tim Leininger, State Public Defenders, Supervisors, Vote to Unionize, J. INQUIRER (Nov. 16, 2016, 11:15 AM), http://www.journalinquirer.com/connecticut_and_region/state-public-defenderssupervisors-vote-to-unionize/article_94b20c44-ac01-11e6-a439-6f489d79609a.html [https://perma.cc/ZZ38-DS36].

147 See, e.g., Mark Gruenberg, Nurses' Union Ratifies Contract with Veterans Administration, PEOPLE'S WORLD (Oct. 15, 2012, 11:58 AM) http://www.peoplesworld.org/article/nurses-unionratifies-contract-with-veterans-administration/ [https://perma.cc/FQE6-5XR4]; Jo Kroeker, Flint Nurse Union to Take Hospital to Court, Detroit News (June 20, 2017, 7:25 PM) http://www.detroitnews.com/story/news/local/michigan/2017/06/20/flint-nurse-pharmacist-unionhospital-court/103054530/ [https://perma.cc/K5LG-TBJY]. 
bargained for additional allotted training hours in firearm proficiency and medical emergency care. ${ }^{148}$

\section{The Impact of Widening the Bargaining Scope in the Public Sector}

Widening the typical scope of bargaining topics to influence organizational policy was a fundamental early victory for public sector unions. That collectively-bargained-for agreements in the public sector still generally encompass a broader scope of activities remains a modern distinction between public and private sector collective bargaining mechanics. Although most state statutes regulating public sector collective bargaining also distinguish between permissive and mandatory subjects, government officials who bargain on the other side of the table with public sector unions have (up until very recently) been more willing to discuss permissive topics than private sector employers. ${ }^{149}$ Unlike in private sector bargaining, a combination of social and political pressures made avoidance of permissive topics in the public sector unpopular. ${ }^{150}$ For example, local school boards were persuaded to give teachers unions a say in school policies or curricula because teachers were the ones actually involved in the day-to-day educational process and teachers were, more often than not, also their constituents. ${ }^{151}$ Moreover, to the extent that teachers' union desires to influence permissive bargaining subjects led to an improved education system, a school board that refused to bargain appeared to take the

148 See, e.g., Boston, Patrolmen's Union Agree to 4-Year, \$68 Million Deal, NewsOK (Feb. 20, 2017, 5:20 AM), http://newsok.com/boston-patrolmens-union-agree-to-4-year-68-milliondeal/article/feed/1170965 [https://perma.cc/F9NS-6W8K]; Kevin Davis, Police Unions \& Officer Survival, OFFICER.COM (Mar. 1, 2012), http://www.officer.com/article/10635548/police-unions-officersurvival [https://perma.cc/E6EF-45WU].

149 See, e.g., Arthur S. Leonard, Collective Bargaining on Issues of Health and Safety in the Public Sector: The Experience Under New York's Taylor Law, 31 BufF. L REV. 165, 166-68 (1982) (noting some of the ways the New York collective bargaining statute urges public employees to bargain over permissive subjects without making them mandatory by law). See generally Juravich \& Bronfenbrenner, supra note 129, at 264-67 (empirical findings suggesting union and collective bargaining employer opposition in general is much lower in the public sector).

150 See Juravich \& Bronfenbrenner, supra note 130, at 269-72.

151 See, e.g., Rebecca Klein, New York Teachers Union Says 'No' To New Education Standards, HuFFINGTON POST (Jan. 27, 2017, 7:10 PM), http://www.huffingtonpost.com/2014/01/27/ny-teachersunion-common-core_n_4676465.html [https://perma.cc/34LG-Y5GV]. Teacher union political influence is not just amplified by the status of their membership making up part of the electorate who elects government officials (many school districts require public school teachers to live in the district where they teach). Empirical evidence also suggests that union members are more likely to vote in general and primary elections and participate in other political and civil activities. See Jasmine Kerrissey \& Evan Schofer, Union Membership and Political Participation in the United States, 91 SoC. FORCES 895, 905-07 (2013); Jan E. Leighley \& Jonathan Nagler, Unions, Voter Turnout, and Class Bias in the U.S. Electorate, 1964-2004, 69 J. POL. 430, 441 (2007). 
universally unpopular political stance of being unwilling to improve education.

Recently, at the urging of labor scholars-who argue that it is both good business sense and good social policy-more private sector employers have been open to unions facilitating additional employee voice into the workplace. ${ }^{152}$ However, even if the scope of bargaining were to widen in the private sector to allow professional employees a voice in organizational policy, the impact of the wider bargaining scope would still affect the public sector differently. ${ }^{153}$ That difference lies in the legitimate third-party interests in public sector bargaining - the interests of citizensin determining public policy. ${ }^{154}$

Arguably, a citizen interest exists in even the "bread and butter" subjects of collective bargaining in the public sector, to the extent that they allocate public resources to one public service over another. ${ }^{155}$ However, a more convincing concern arises when public unions negotiate bargaining subjects that affect public policy, circumventing the ordinary legislative and administrative processes for determining such issues. ${ }^{156}$ Again, the public education sphere is littered with examples of this, where subjects like curricula and class size were decided by teachers unions and school boards at the bargaining table, denying parents and community members a voice in determining their outcome. ${ }^{157}$ But teachers unions are not alone in bargaining over subjects with major policy implications.

152 See Dau-Schmidt, supra note 143, at 804-09 (suggesting that worker voice in the private sector can enhance productivity as on-the-ground employees often have useful insight concerning methods of production and that employee voice reduces turnover costs; moreover, promoting employee voice promotes social workplace norms, solves the problem of negotiating public goods in the workplace, and views workers more as humans than commodities); see, e.g., ChARLES C. HeCKSCHER, THE NEW Unionism: Employee involvement in the Changing CoRporation 8-9, 77-81, 224 (1988) (arguing that the current legal framework-including exclusive representation, a clear line between exempt managers and nonexempt workers, and arbitrary lines between working conditions and managerial domain - freezes industrial relations and inhibits needed changes); THOMAS A. KOCHAN ET AL., The TRANSFormation of American Industrial Relations 234-36 (1986) (noting that innovations in industrial relations "challenge" doctrines of employer domination, exclusive representation, distinctions between workers and supervisors, and distinctions among bargaining subjects).

153 See Wellington \& Winter, JR., supra note 82, at 22 (1971) (arguing that the impact of expanding the scope is not only different but also "much more troublesome" in the public sector).

${ }^{154} I d$. at $29,137-42$.

155 Id. at $17-18$.

156 Id. at $141-42$.

157 See id. at 137-38 (observing early collective agreements in New York City and New Haven addressing class size in 1963 and 1969); see also Frederick M. Hess \& Andrew P. Kelly, Scapegoat, Albatross, or What?: The Status Quo in Teacher Collective Bargaining, in COLLECTIVE BARGAINING IN EduCATION: Negotiating ChANGe IN TODAY's Schools 53, 82 (Jane Hannaway \& Andrew J. Rotherham eds., 2006); Charles T. Kerchner, Union-Made Teaching: The Effects of Labor Relations on 
Indeed, police unions also have been besieged by social activist groups claiming that bargained-for contract provisions-such as those addressing investigations into the use of force or police misconductshield officers from accountability at the community's expense. ${ }^{158}$ Recently the City of Chicago illustrated one of the most striking examples of this. After a police officer shot seventeen-year-old Laquan McDonald sixteen times in the back, the grievance procedure contained in the collectively bargained-for police agreement allowed him to remain on the city's payroll for over a year following the incident. ${ }^{159}$ Other provisions within the collective bargaining agreement protected the officer's identity from the public, barred investigators from reviewing his past record of civilian complaints, and prevented the city from charging him or any other officers involved for the false statements made during the investigation, even though a dashboard camera video later proved those statements unequivocally false. ${ }^{160}$ The entire incident prompted Chicago Mayor Rahm Emanuel to remark that such collective bargaining agreements have "essentially turned the [police] code of silence into official policy." 161

Renowned legal scholars Harry Wellington and Ralph Winter warned of public sector unions' potential to disproportionately impact the political process in the early 1970s, and Justice Powell's Abood concurrence showed remarkable foresight in this area. But the true scope of public sector

Teaching Work, 13 REV. RES. EDUC. 317, 327 (1986). Other states have removed the issue of class size from bargaining by addressing it in separate statutory provisions. Florida voters ratified a constitutional amendment in 2002 to reduce class sizes to 18 for prekindergarten through Grade 3, 22 for Grades 4 through 8, and 25 for Grades 9 through 12. FLA. CONST. art. IX, § 1 (2002); see also S.J. Res. 2, 112th Leg. (Fla. 2010) (joint resolution proposing to amend Article IX, Section 1, of the Florida Constitution relating to class sizes, revising language so that maximum and minimum class size requirements apply to each school's class grade average and not every class individually)

158 See Conor Friedersdorf, Black Lives Matter Takes Aim at Police-Union Contracts, ATLANTIC (Dec. 7, 2015) https://www.theatlantic.com/politics/archive/2015/12/black-lives-matter-takes-aim-atpolice-union-contracts/418530/ [https://perma.cc/N99G-MQH7] (noting that several cities have collective bargaining agreements with police unions that require delays before an officer investigated for use of force can be interviewed, mandatory paid leave when an officer discharges a weapon, and the protection of their identity from the public).

159 See Editorial Board, When Police Unions Impede Justice, N.Y. TIMES, Sept. 4, 2016, at SR8; Adeshina Emmanuel, Chicago Police Contract Scrutinized in the Aftermath of Laquan Mcdonald's Death, CHI. REP. (Dec. 10, 2015), http://chicagoreporter.com/chicago-police-contract-scrutinized-inthe-aftermath-of-laquan-mcdonalds-death/ [https://perma.cc/3LBF-JXZQ]; Nausheen Husain, Laquan McDonald Timeline: The Shooting, the Video, and the Fallout, CHI. TRIB. (June 27, 2017, 6:13 PM), http://www.chicagotribune.com/news/laquanmcdonald/ct-graphics-laquan-mcdonald-officers-firedtimeline-htmlstory.html [https://perma.cc/H8C7-6TR4]; Agreement Between Fraternal Order of the Police Chicago Lodge No. 7 and the City of Chicago (July 1, 2012), https://static1.squarespace.com/ static/5516f090e4b01b711314608f/t/55d0b066e4b0c6285c50236b/1439740006221/Chicago-FOPContract.pdf [https://perma.cc/Q376-ZRMT].

160 Emmanuel, supra note 159.

161 Editorial Board, supra note 159. 
collective bargaining, and the extent of its impact, could not have been known. ${ }^{162}$ In fact, even now in contemporary public workplaces, we only know for sure that to the extent union activities influence public policy, "[n]othing endures but change." 163 Public sector union activity and influence is always shifting, context specific, politically dependent, and responsive to technological initiatives. Fortunately, state and local lawmakers have proven proficient and flexible cartographers when it comes to mapping out the boundaries of collective bargaining to fit the needs of their jurisdiction.

\section{The External Evolution: Legislation}

Abood addressed a Michigan public sector collective bargaining statute in its earliest form, when it was most similar to the private sector federal model. ${ }^{164}$ Unlike their predecessors, public sector labor laws have proven much more tolerant of innovation, existing in a wide variety of models today throughout state and local jurisdictions. ${ }^{165}$ In a genuine illustration of states working as laboratories of democracy, ${ }^{166}$ state lawmakers have modified their public sector collective bargaining legislation to experiment with and evaluate solutions addressing a variety of issues. ${ }^{167}$ Solutions to issues directly relating to the political nature of

\footnotetext{
162 See supra notes 144-48; see also Abood v. Detroit Bd. of Educ., 431 U.S. 209, 223 (1977).

163 The YAle Book of Quotations 356 (Fred R. Shapiro ed., 2006) (thought to be attributable to the ancient Greek philosopher Heraclitus).

164 See Abood, 431 U.S. at 212-14, 222. Like most states, Michigan's first collective bargaining statute was modeled after federal law with many provisions nearly identical to the NLRA and RLA. Id.; MicH. COMP. LAWs $\S \S 423.201-217$ (1979).

165 Ann C. Hodges, Lessons from the Laboratory: The Polar Opposites on the Public Sector Labor Law Spectrum, 18 CoRnell J.L. \& PUB. POL'Y. 735, 735 (2009); see also Cynthia L. Estlund, The Ossification of American Labor Law, 102 COLUM. L. REV. 1527, 1531-32 (2002) (describing the institutional barriers that have left private sector labor law virtually untouched since the LandrumGriffin Act of 1959, much to the frustration of reform advocates).

166 New State Ice Co. v. Liebmann, 285 U.S. 262, 311 (1932) (Brandeis, J., dissenting) (Justice Louis Brandeis popularizing the concept of state and local governments as laboratories to enact and test new social and economic policies).

167 Id.; see also Hodges, supra note 165, at 737-48. For additional experimental efforts in state labor legislation, see Cal. Gov’t Code $\S \S 3500-3511$ (West 2001.), as explained in Joseph R. Grodin, Public Employee Bargaining in California: The Meyers-Milias-Brown Act in the Courts, 23 Hastings L.J. 719, 720-21, 737 (1972) (California experimenting with a proportional, as opposed to an exclusive representation labor statute for public employees from 1961 to 1976), and see also WIS. STAT. ANN. $\S 111.70(1)(\mathrm{nc})$ (1993), repealed by A.B. 75, § 2224, 99th Leg. (Wis. 2009), as explained in Martin Malin, The Legislative Upheaval in the Public Sector: A Search for Common Elements, 27 ABA J. LAB. \& EMP. LAW 149, 151 \& n.16 (2012) (discussing Wisconsin's 1993-2009 experimentation with a qualified economic offer (QEO) bargaining prohibition, which preempted bargaining over school employee wages if a school district's wage offer met a prescribed formula). In 2009, Wisconsin repealed the QEO. Id.
} 
public sector collective bargaining have already been worked into many state and local legal frameworks. These issues include the permission and collection methods of agency fees and the scope of bargaining subjects, and their resolution is part of an ongoing effort by states to build the most responsive model for their jurisdictions. States' significantly different and often-modified public sector collective bargaining statutes now merit additional consideration and weight in future litigation. Put another way, thanks to states' flexibility in amending, eliminating, and narrowing their public sector collective bargaining regimes over the last few decades, all agency fees, their permitting statutory provisions, and the stated justifications behind them are not created equal.

\section{Legislative Limits to Collective Bargaining}

To restrict the impact public sector unions had on public policy, states began narrowing the scope of public sector collective bargaining subjects by statute and judicial interpretation as early as the 1980 s. ${ }^{168}$ Not surprisingly, these early exclusions concerned teachers unions and the somewhat controversial bargaining topics that related to educational initiatives. In 1982, New Jersey made school curriculum, class size, and the length of the school day illegal bargaining topics because they were to be decided "not by negotiation . . but by the political process." ${ }^{169}$ Kansas, ${ }^{170}$ Delaware, ${ }^{171}$ Maine, ${ }^{172}$ and Nevada ${ }^{173}$ soon followed with their own excluded bargaining topics for teachers unions. Michigan would amend its collective bargaining laws in the 1990s to prohibit teachers unions from bargaining over an enumerated list of topics, such as the privatization of non-instructional educational services, charter school approval, and the starting day of the school term. ${ }^{174}$ In 2011, Michigan amended its statute

\footnotetext{
168 See supra notes $155-62$.

169 In re Local 195 v. State, 443 A.2d 187, 191 (N.J. 1982)

170 S.B. 551, Ch. 167 (Kan. 2002) (codified at KAN. STAT. ANN. § 72-5413(1)(3) (2015)) (making school term and school hours not subject to bargaining).

171 Colonial Sch. Bd. v. Colonial Affiliate, 449 A.2d 243, 247 (Del. 1982) (topics other than "salaries, employee benefits, and working conditions" are prohibited from bargaining).

172 Me. Rev. Stat. AnN. tit. 26, § 965(1)(c) (2014) (excluding "educational policies" from scope of bargaining).

173 NEV. REV. STAT. § 288.150 (1975) (removing "[a]ppropriate staffing levels and work performance standards," the "quality and quantity" of public services, and "[t]he means and methods of offering these services" from the scope of bargaining).

1741994 Mich. Pub. Acts No. 112 (codified at Mich. Comp. Laws AnN. § 423.215 (West 2014)); see also Malin, supra note 167, at 151, 159 (noting that twice-elected Michigan governor John Engler campaigned forcefully on educational reform initiatives); Benjamin M. Superfine \& Jessica J. Gottlieb, Teacher Evaluation and Collective Bargaining: The New Frontier of Civil Rights, 2014 MicH. ST. L. REV. 737, 746-49 (describing how the large-scale education policy reform of the late 1980s and early 1990s bred a climate that elected John Engler and embraced collective bargaining restraints on teacher
} 
again to prohibit teacher union bargaining over, inter alia, teacher placements, performance evaluations, and education standards. ${ }^{175}$

Instead of listing the excluded bargaining subjects, Idaho and Indiana have preferred to limit the scope of teacher union bargaining by listing the allowable bargaining subjects within their statutes and expressly prohibiting everything else. ${ }^{176}$ Wisconsin's collective bargaining statute explicitly limits the scope of bargaining for all public sector employees (except for police, firefighters, and municipal transit employees) to the single issue of "base wages." 177 Other bargaining topics are prohibited. ${ }^{178}$ Some states have, for policy reasons, taken away all bargaining rights for specific types of public employees, while others have prohibited particular bargaining subjects like healthcare across the board. ${ }^{179}$

While the state initiatives above exemplify attempts to limit the scope of bargaining on policy issues, other states have preserved bargaining rights over these same matters by statute or case law, even making some not just permissive but mandatory bargaining subjects. Illinois and California, for example, have both experimented with "class size" as a mandatory bargaining subject for teachers unions and their employers. ${ }^{180}$ Despite the state having a broad scope of bargaining subjects for its public employees, California has crafted other alternatives for the public to be heard on bargaining matters related to policy. For instance, for some classes of

unions). The igniting spark to such reform was the 1983 report $A$ Nation at Risk. Drafted by the National Committee on Educational Excellence, the report viewed America's educational system as a national crisis, noting that: "[T]he educational foundations of our society are presently being eroded by a rising tide of mediocrity that threatens our very future as a Nation and a people." DAVID P. GARDNER

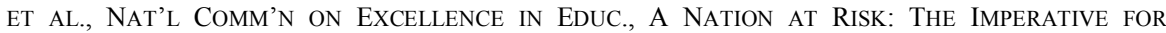
EDUCATIONAL REFORM 13 (1983), http://files.eric.ed.gov/fulltext/ED226006.pdf [https://perma.cc/JU7M-QNB4].

1752011 Mich. Pub. Acts No. 103.

176 IDAHO CODE ANN. § 33.1272 (West 2017); IND. CODE ANN. § 20-29-6-4 to -4.5 (West 2017).

177 Wis. STAT. ANN. § 111.91(3) (West 2017).

$178 I d$. For another interesting state model on regulating the bargaining scope, but still preserving a professional element of choice, see the current Kansas statute regarding teacher contract bargaining, KAN. STAT. ANN. § 72-5423(b)(1) (2015). This statute requires that, along with compensation and the required amount of hours, each party may select no more than three additional "terms and conditions of professional service" from an enumerated list as mandatory bargaining topics. $I d$. All other terms and conditions not selected are then deemed permissive bargaining topics, only subject to negotiation if the parties mutually agree. $I d$.

179 See S.B. 98, § 76th Leg., Reg. Sess. § 6 (Nev. 2011) (codified at NEv. Rev. STAT. § 288.140 (2011)) (removing bargaining rights from physicians, lawyers, and supervisors); see also MASS. GEN. LAWS ANN. ch. 32B, § 23(a) (West 2017); N.J. STAT. ANN. § 18A:16-17.1.a. (West 2017)

180 CAL. Gov'T CODE $§ 3543.2$ (West 2015); 115 Ill. CoMP. STAT. 5/10 (1984); see also Decatur Bd. of Educ. v. Ill. Educ. Labor Relations Bd., 536 N.E.2d 743, 744 (Ill. App. Ct. 1989) (interpreting class size as a mandatory bargaining subject under $115 \mathrm{Ill}$. Comp. Stat. $5 / 10$ because class size "directly affected terms and conditions of employment"). 
public employees, their legislative scheme requires that all initial bargaining proposals be presented at a public meeting so citizens may express their views. ${ }^{181}$

\section{Legislative Limits to Agency Fees}

Aside from "right to work" states, which prohibit all agency fee agreements in both the private and public sectors, states have limited agency fee rights and their influence on political activity through a variety of other statutory forms. ${ }^{182}$ For example, several states have proposed "paycheck protection" laws that prohibit the deduction of union dues or agency fees from public employee paychecks. ${ }^{183}$ Alabama, for example, tested a statutory prohibition on the political use of any money collected through public employee payroll deductions, and Michigan barred the payroll deduction of all union dues for only public school teachers. ${ }^{184}$ Others have experimented with "opt in" paycheck legislation, which would require employees to reauthorize annually if they wish to have union dues/agency fees deducted from their paychecks. ${ }^{185}$ Other proposals have required unions to obtain written consent from members in order to deduct money from their paychecks for political purposes. ${ }^{186}$

\footnotetext{
181 CAL. GOV'T CODE $§ 3547$ (West 2015).

182 See Kenneth Glenn Dau-Schmidt \& Winston Lin, The Great Recession, the Resulting Budget Shortfalls, the 2010 Elections and the Attack on Public Sector Collective Bargaining in the United States, 29 Hofstra LAB. \& EMP. L.J. 407, 428-31 (2012) (describing the passage of right to work legislation from the Taft-Hartley amendments in 1947 through 2012). When this Article went to print, twenty-eight states were right to work states with Missouri being the last to enact legislation in February 2017. Right to Work: Frequently Asked Questions, NAT'L Right to WORK Legal DeF. FOUND. (2017), http://www.nrtw.org/right-to-work-frequently-asked-questions [https://perma.cc/55DBYNZ7]. However, even right to work exists on a spectrum in the laboratory that is state labor law. For example, Indiana, which passed right to work legislation in the 1950s and then repealed it in the 1960s, is now right to work again as of 2012. Dau-Schmidt \& Lin, supra, at 428-31. Moreover, ten states have actually included right to work provisions in their constitutions, presumably to make them harder to repeal. Id. at 429 n.152.

183 See, e.g., ARIZ. ReV. StAT. ANN. § 23-361.02). But see N.C. GEN. STAT. §§ 95-98 (2017); VA. CODE. ANN. $\S \S 40.1-57.2$ (2017) (although North Carolina and Virginia bar public sector collective bargaining, both states allow for the payroll deduction of union dues).

184 AlA. CODE § 17-17-5 (2010); ARIZ. REv. STAT. ANN. § 23-361.02 (2016). The 2010 Alabama Act amending Alabama Code $\S 17-17-5$ with payroll deduction prohibitions was enjoined from taking effect based on a First Amendment challenge in Ala. Educ. Ass'n v. Bentley, 788 F. Supp. 2d 1283, 1327-28 (N.D. Ala. 2011), rev'd sub nom. Ala. Educ. Ass'n v. State Superintendent of Educ., 746 F.3d 1135 (11th Cir. 2014). The Eleventh Circuit narrowed the injunction, however, allowing the law to take effect so long as it applied only to dues deductions for electioneering activities. State Superintendent of Educ., 746 F.3d at 1153.

185 See, e.g., S.B. 5000, 53rd Leg. (Wash. 1993).

186 See, e.g., H.R. 1625, § 4, 105th Cong. (1997); H.R. 3580, 104th Cong. (1996); California Proposition 226 (June 2, 1998).
} 
At least two states, New Jersey and Minnesota, have set statutory maximums for agency fees as they relate to the full cost of union member dues within the same bargaining unit. ${ }^{187}$ And although California allows for agency fee agreements within the public sector, its statute also includes provisions allowing for the rescission of such agreements by a majority vote of the bargaining unit employees. ${ }^{188}$

Comparing the different statutory forms and scopes of state legislative collective bargaining and agency fee models demonstrates that states come up with their own solutions and create their own boundaries for public unions and their political activity. Abood's bright line, however, displaces their working boundaries and legislative efforts.

\section{E. The External Evolution: Public Perception}

With the early concerns about public sector collective bargaining put to rest, public sector unions were widely accepted by the public on both sides of the political aisle by the late 1970s. Indeed, Abood marked the beginning of a period of unwavering public approval for public sector unions, a remarkable feat considering the continued decline of their private sector counterparts. ${ }^{189}$ If unions in the private sector were dominated by competition, turbulence, and uncertainty in the 1980s, 1990s, and early 2000 s, public unions by contrast were their secure and stable younger siblings.

Success ushered in more success. With public sector workers able to choose unions and enjoy labor relations in a climate largely free from the threats and intimidation that were commonplace in the private sector, even more public workers lined up for representation. ${ }^{190}$ This prevailing enthusiasm enabled most public sector unions to win certification elections by large margins in the ' 80 s and ' 90 s, despite running low-intensity organizing campaigns. ${ }^{191}$ Public sector unions' esteem meant that in addition to employers offering little to no opposition to certification, state and local officials negotiated favorable deals to preserve their relationships with these popular institutions. ${ }^{192}$ These favorable deals only bolstered the

\footnotetext{
187 See MINN. STAT. § 179A.06 (3) (2012) (fair share fees are not to exceed 85\% of regular membership dues); N.J. STAT. ANN. § 34:13A-5.5(b) (West 2002).

188 CAL. GOV'T CODE $\S 3515.7$ (d) (West 2015).

189 See Robert Hebdon et al., Public Sector Collective Bargaining: Tumultuous Times, in Collective Bargaining Under Duress: CASE Studies of MAJOR NORTH AMERICAN INDUSTRIES 255, 257 (Howard R. Stranger et al. eds., 2013). Public sector union density remained extraordinarily constant from 2001 (36.8\%) to 2011 (37.0\%). Id.

190 See Juravich \& Bronfenbrenner, supra note 130, at 262-64, 269.

191 Id. at 264-66, 269.

192 Id. at 266-68.
} 
public sector unions' claims that they provided a valuable service to their membership that was worth the investment. ${ }^{193}$

\section{The Great Recession}

Public sector unions were not the only ones feeling secure by the mid2000s, as prosperity was in full swing throughout the United States. ${ }^{194}$ Fueled by historically low interest rates, low unemployment, and accessible credit, an unprecedented number of American households became homeowners through subprime mortgages. ${ }^{195}$ High demand caused the median home value to skyrocket, and as home values rose, more families spent money as if they were wealthier than their true salaries and wages suggested. ${ }^{196}$ As large segments of the population prospered, a "trickle up" effect occurred in the budget offices of state and local governments. ${ }^{197}$ Amidst budget surpluses fueled by sales and property tax increases, states and local governments went on spending sprees - increasing public wages, building infrastructure, and even authorizing resident rebates - in lieu of saving for a rainy day. ${ }^{198}$

193 See Richard W. Hurd \& Tamara L. Lee, Public Sector Unions Under Siege: Solidarity in the Fight Back, 39 LAB. STUD. J. 9, 11-12, 19 (2014).

194 See Thom ReILly, supra note 123, at 3-4 (2012). Of course, private sector unions-which have been in decline since the mid $1980 \mathrm{~s}$ - were one noteworthy exception to the economic prosperity experienced in the early 2000s. See Megan Dunn \& James Walker, U.S. Bureau OF Labor Statistics, Union Membership IN the United States 1 (2016), https://www.bls.gov/spotlight/2016/union-membership-in-the-united-states/pdf/union-membership-inthe-united-states.pdf [https://perma.cc/Y2EQ-QS63].

195 Katalina M. Bianco, The Subprime Lending Crisis: Causes and EfFects of the MORTGAGE MELTDOWN 1, 6 (2008) https://business.cch.com/images/banner/subprime.pdf [https://perma.cc/2YRW-MJM5]. See generally NeVA GoOdwIN ET AL., MACROECONOMICS IN CONTEXT ch. 15 (2nd ed. 2017) (providing background on the "Financial Crisis and the Great Recession"). A subprime mortgage is a type of high interest or adjustable interest mortgage issued to borrowers with low credit ratings. They are issued to individuals who do not qualify for a conventional mortgage because of their high risk of default. Between 1996 and 2006, the national share of subprime mortgage to total mortgage originations increased from nine percent to twenty percent. BIANCO, supra, at 6.

196 See Jeff Holt, A Summary of the Primary Causes of the Housing Bubble and the Resulting Credit Crisis: A Non-Technical Paper, 8 J. Bus. INQUIRY 120, 125-26 (2009). After the housing bubble inflated home values, homeowners-believing that their home's value would continue to increase as it had every year in the past since the Great Depression - withdrew high amounts of equity out of their newly valued home to spend. Id. at 126-27. In 1996, former Federal Reserve Chair Alan Greenspan famously called this phenomenon "irrational exuberance." Alan Greenspan, Chairman, Fed. Reserve of the U.S., The Challenge of Central Banking in a Democratic Society, Remarks at the Annual Dinner and Francis Boyer Lecture of the American Enterprise Institute for Public Policy Research (Dec. 5, 1996), https://www.federalreserve.gov/boarddocs/speeches/1996/19961205.htm [https://perma.cc/643C-YEYZ].

197 See ReILly, supra note 123 , at 4.

198 "States predominantly tax income and sales, while localities depend primarily on property taxes." Tracy Gordon, State and Local Budgets and the Great Recession, BROOKINGS (Dec. 31, 2012), 
But in 2007, the United States housing market collapsed under a slew of high-risk subprime mortgages that went unpaid. Knee-deep in defaulting loans, many banks and lending institutions panicked and tried to quickly sell off bad mortgages on Wall Street as cheaply as possible. ${ }^{199}$ Moreover, banks, now paralyzed by their toxic assets and looking to hoard cash, stopped lending, causing a credit crisis that effectively froze the American economy and began a countrywide recession. ${ }^{200}$ The recession lasted officially from December 2007 through June 2009, and its impact was felt so universally throughout the American economy that modern economists now refer to it as just the "Great Recession." 201

\section{After the Great Recession}

After the Great Recession, federal and state government deficits surged as tax revenues fell to historic lows and demands for public programs rose. ${ }^{202}$ Although Congress initially helped offset states' longterm budgeting gaps with unprecedented fiscal relief in the form of the $\$ 787$ billion American Recovery and Reinvestment Act of 2009 (ARRA), the problem only intensified in fiscal years 2010, 2011, and 2012 as ARRA funds dried up. ${ }^{203}$ Thus, faced with impending budgeting shortfalls, states

http://www.brookings.edu/articles/state-and-local-budgets-and-the-great-recession/

[https://perma.cc/5QGT-7K34]; see also NAT'L ASS'N OF STATE BUDGET OfFICERS, STATE EXPENDITURE REPORT 61, 64 (2011); REILLY, supra note 193, at 4 (noting that Utah approved a \$1 billion long-term road and highway plan during this prosperous period, while the Nevada state legislature in 2005 actually approved a rebate to every Nevada resident who owned a vehicle, after the state's gas tax helped produce a $\$ 300$ million state surplus).

199 See Manav Tanneeru, How a 'Perfect Storm'Led to the Economic Crisis, CNN (Jan. 29, 2009), http://www.cnn.com/2009/US/01/29/economic.crisis.explainer/index.html [https://perma.cc/MWC9ZHFA].

200 See Holt, supra note 196, at 125.

201 See Paul Krugman, Opinion, The Great Recession Versus the Great Depression, N.Y. TIMES (Mar. 20, 2009, 4:35 PM), https://krugman.blogs.nytimes.com/2009/03/20/the-great-recession-versusthe-great-depression [https://perma.cc/6N3M-BC7N] (Krugman, a Nobel Prize-winning economist and New York Times columnist, labeling the recent crisis as the "Great Recession"). For this paper, the author refers to the period of recession following the mortgage and financial crisis as the "Great Recession." See REILLY, supra note 123, at 5-6. At its worst, unemployment would rise to $10.1 \%$ as more than 14 million people found themselves out of work, and America's household net worth would fall from $\$ 66$ trillion to $\$ 49$ trillion. Moreover, more than 3.5 million homes would be returned to the banks who financed their mortgage. $I d$. at 5 .

202 See Gordon, supra note 198, at 4 (citing to the U.S. Census Bureau figures). State and local revenues fell during the Great Recession after sales taxes, income taxes, and property taxes plummeted. Id. At their lowest, in 2009 state taxes were down 17\% from where they were one year before. Id. During these revenue declines, spending pressures - specifically in the form of increased enrollments for Medicaid, unemployment insurance, and higher education-increased. Id.

203 American Recovery and Reinvestment Act of 2009 (ARRA), Pub. L. No. 111-5, § 1553(a)(1), 123 Stat. 115, 297 (2009); see also Edward Ashbee, The Obama Administration, the Promise of Reform, and the Role of Business Interests, in ISSUES IN AMERICAN POLITICS POLARIZED POLITICS IN THE AGE OF OBAmA 57, 62 (John Dumbrell ed., 2013); Gordon, supra note 198, at 7. 
cut spending on education, healthcare, and social services; raised fees related to businesses, court access, and higher education; and negotiated significant concessions in their employee collective bargaining agreements. ${ }^{204}$ Other states raised taxes to balance their budgets in spite of strong opposition from a beaten-down constituency. ${ }^{205}$

Myriad voters in economic distress were the perfect amplifiers for conservative Republican songs of government being too large and expensive. Thus, despite President Barack Obama's victory in 2008, the Great Recession and the country's slow economic recovery brought forth a political shift during the 2010 midterm elections. ${ }^{206}$ Many voters now perceived state governments" overspending as an "ideological overreach" and, in response, delivered significant election victories to Republican candidates - specifically Tea Party-aligned candidates-who promised smaller government and lower taxes. ${ }^{207}$ The Democratic Party's shellacking in 2010 gave control of the House to Republicans, who also claimed six new seats in the Senate. ${ }^{208}$ At the state level, the losses proved to be even greater as Republicans took complete control of twenty states after winning eleven new governorships and eighteen additional state legislatures. ${ }^{209}$

Republicans' new control of both legislative and executive branches at the state level set the stage for a startlingly coordinated national campaign

204 See REILLY, supra note 123, at 6-7.

205 See, e.g., Norimitsu Onishi, Californians Back Taxes to Avoid Education Cuts, N.Y. TIMES, (Nov. 7, 2012), http://www.nytimes.com/2012/11/08/us/politics/in-california-voters-approve-ballotmeasure-that-raises-taxesin-california-approve-voters-ballot-measure-that-raisestaxes.html? module=Search\&mabReward=relbias $\% 3 \mathrm{Aw} \% 2 \mathrm{C} \% 7 \mathrm{~B} \% 221 \% 22 \% 3 \mathrm{~A} \% 22 \mathrm{RI} \% 253$

[https://perma.cc/L94M-S4QN] ; THE PEW Charitable Trust, AN INCREASE IN ProperTy AND

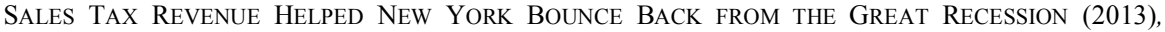
http://www.pewtrusts.org/ /media/assets/2013/11/11/new_york_profile.pdf?la =it [https://perma.cc/EU36-VBLU] (describing the property and sales tax increases in California and New York during the Great Recession).

206 See Paul Harris \& Ewen MacAskill, US Midterm Election Results Herald New Political Era as Republicans Take House, THE GUARDIAN (Nov. 3, 2010, 12:22 PM), https:/www.theguardian.com/ world/2010/nov/03/us-midterm-election-results-tea-party [https://perma.cc/55WU-HSS7].

207 See Larry M. Bartels, Political Effects of the Great Recession 12 (Vanderbilt Univ. Center for the Study of Democratic Insts., Working Paper No. 6-2013, 2013), http:/www.vanderbilt.edu/ csdi/research/CSDI_WP_06-2013.pdf [https://perma.cc/5HK4-MYYB]; see also THEDA SKOCPOL \& VAnessa Williamson, The TeA PARTy AND THE REMAKIng of REPUblican CONSERVATISM 4 (2012).

208 See Bartels, supra note 207, at 12.

209 See NAT'l CONFERENCE of StATE Legislatures, 2010 StATE AND LeGiSlative Partisan COMPOSITION (2010), http://www.ncsl.org/documents/statevote/LegisControl_2010.pdf [https://perma.cc/AG4L-YQ7R]; $c f$. NAT'L CONFERENCE OF STATE LEGISLATURES, 2011 STATE AND LEGISLATIVE PARTISAN COMPOSITION (2011), http://www.ncsl.org/documents/statevote/ LegisControl_2011.pdf [https://perma.cc/5TVB-ZX6T] (illustrating the over 700 seats lost by Democrats in state legislatures during the 2010 midterm election). 
against big government, the "privileged" public worker, and the public sector unions that sustained them. ${ }^{210}$ With help from conservative editorials and free market special interests groups like the American Legislative Exchange Council (ALEC) and the Mackinac Center, Republican lawmakers made public union workers - and their salaries, benefits, and pension costs - the scapegoats for high taxes and state budget deficits. ${ }^{211}$ These groups proved dramatically successful in changing the fifty-year-old narrative of the humble, modest-living public servant into an "elite class" of public pension millionaires, siphoning public resources and opposing privatization and progressive change. ${ }^{212}$

Armed with this new narrative of the overcompensated public worker and a library of predrafted legislation, lawmakers got to work, fervently introducing legislation to weaken public sector collective bargaining in 2011. Over the next two years, 733 bills in 42 states relating to public employee unions were introduced, and 21 states would pass some form of

210 See Hurd \& Lee, supra note 193, at 14; see also Monica Davey, One-Party Control Opens States to Partisan Rush, N.Y. Times, Nov. 22, 2012, at A1 (noting that state legislatures have become more partisan on both ends of the political spectrum, enabling activists to push through their agendas). In 2013, a single party maintained complete government control over more state governments (thirtyseven) than any other time within the last sixty years. See Davey, supra. "Complete government control" within this context refers to one party holding the governor's office and majorities in both legislative chambers.

211 See JAson Stein \& Patrick Marley, More than They BARgained For 39-41 (2013). ALEC is a membership organization comprised of state legislators and corporations for the purpose of drafting free market model legislation. Although it brands itself as a "nonpartisan" partnership between officials and leaders in commerce, the "partnership"-which includes inter alia corporate members Exxon Mobil, Pfizer Pharmaceuticals, Wal-Mart, Phillip Morris, and Koch Industries-has been criticized by some for its ties to other well-known conservative donors and think tanks like the Bradley Foundation, the Heritage Foundation, Goldwater Institute, and the Mackinac Center for Public Policy. Id. at 40-41. The Mackinac Center is the largest think tank devoted to state-level policies. Its contributions to the events in Wisconsin are noteworthy in discussing the change in public perception because they are considered the experts in constructing favorable narratives of right-wing objectives. Mackinac Center Vice President and former research scholar Joseph P. Overton invented the concept of the Overton Window, which describes policy positions that are acceptable to the public. "Shifting the window" is the process of making previously unthinkable positions appear acceptable or vice versa. See Joseph Lehman, The Overton Window: A Model of Policy Change, MaCKInAC CTR. FOR PUB. POL'Y (last visited Feb. 1, 2018), https://www.mackinac.org/OvertonWindow [https://perma.cc/DR7V4W9V].

212 See, e.g., Andrew Biggs \& Jason Richwine, The Public Worker Gravy Train, WaLl St. J., Feb. 24, 2011, at A15; Tim Pawlenty, Government Unions vs. Taxpayers, WALL ST. J., Dec. 13, 2010, at A19; The Government Pay Boom, Wall St. J., Mar. 26, 2010, at A18; Andrew G. Biggs, How to Become a (Public Pension) Millionaire; In Five States, an Average Full-Career Retiree Receives a Retirement Income Higher than His Final Salary, WALL ST. J. (Mar. 14, 2014), https:/www.wsj.com/ articles/andrew-biggs-how-to-become-a-public-pension-millionaire-1394834779

[https://perma.cc/R7BR-4XRM]. But see Jeffrey H. Keefe, State and Local Public Employees: Are They Overcompensated?, 27 ABA J. LAB. \& EMP. L. 239 (2012) (data analyses indicating that the total compensation package of state and local public employees - when controlled for factors like education and experience - is on average $3.7 \%$ less than similar employees in the private sector). 
legislation limiting public sector collective bargaining. ${ }^{213}$ Because the media covered many of these attempts extensively, and they have since been the topic of admirable scholarly works, this Article relies on prior scholarly contributions and does not review all of these attacks in detail. ${ }^{214}$ It will instead focus on two particularly poignant moments that encapsulate the shifting public opinion of public sector collective bargaining after 2010 .

\section{Wisconsin and New Jersey}

The first was a confrontation between New Jersey Governor Chris Christie and an elementary school art teacher, Marie Corfield. After cutting into state aid for education, laying off teachers, and using some disdainful words to describe New Jersey's public education system, the new Governor held a town hall meeting, which Ms. Corfield attended. ${ }^{215}$ During their interaction, which was captured on video, Ms. Corfield timidly asked the Governor how his reforms will help the middle class when "so many middle-class teachers are spending tons of money out of their pocket to supplement the budgets that were cut so they can buy supplies." ${ }^{216}$ Governor Christie's responded dismissively to her claims that she "would have a hard time paying her bills" after the cuts, his demeanor aggressive as he accused Ms. Corfield of showmanship and his tone pugnaciousness and filled with contempt as he defended his "lambasting" of New Jersey's teachers union. ${ }^{217}$ However, if one were to guess which person received a stream of abusive emails and Facebook postings in response to the video,

213 See Dau-Schmidt \& Lin, supra note 182, at 413 (observing that of these twenty-one states, twelve of them-Wisconsin, Ohio, Indiana, Arizona, Idaho, Michigan, New Hampshire, Oklahoma, South Carolina, Tennessee, Utah, and Wyoming - passed "significant restrictions on public sector collective bargaining"). ALEC highlighted several model bills designed to limit public sector collective bargaining at its biannual Task Force Summit in December 2010. These model bills were introduced in several state legislatures, nearly unaltered, over the next two years. STEIN \& MARLEY, supra note 211, at 39 .

214 See generally Dau-Schmidt \& Lin, supra note 182; Martin H. Malin, Life After Act 10?: Is There a Future for Collective Representation of Wisconsin Public Employees?, 96 MARQ. L. REV. 623 (2012); Martin H. Malin, Sifting Through the Wreckage of the Tsunami that Hit Public Sector Collective Bargaining, 16 EMP. RTS. \& EMP. POL'Y J. 533 (2012); Malin, supra note 167; Slater, supra note 58; Bryan J. Soukup, From Coolidge to Christie: Historical Antecedents of Current Government Officials Dealing with Public Sector Labor Unions, 64 LAB. L.J. 177 (2013).

215 See, e.g., Amanda Carey, New Jersey Governor Chris Christie Blasts Teachers' Unions (Again) in Washington, D.C. Speech, DAILY CALLER (Jan. 1, 2010, 1:24 AM), http://dailycaller.com/ 2010/12/01/new-jersey-governor-chris-christie-blasts-teachers-unions-again-in-washington-d-c-speech/ [https://perma.cc/P6YY-8Z34].

216 See GovChristie, Governor Christie Responds to Teacher During Town Hall, YouTUBE (Sept. 8, 2010), https://www.youtube.com/watch?v=PkuTm-ON904 [https://perma.cc/R9TT-SW3B]. This video went viral after Governor Christie's staff shared it on his website. To date, it has been viewed almost 1.5 million times. Id.

${ }^{217}$ Id. 
and which one was celebrated as a YouTube sensation, one would probably be wrong. Conservatives praised the New Jersey governor and school choice advocate for taking on his state's obstinate public sector unions. ${ }^{218}$ The elementary school art teacher got hate mail. ${ }^{219}$

The second example of the public shift was Wisconsin's enactment of Act 10. While adequate prior coverage does not require this Article to recall the collective bargaining restrictions in Act 10, the protestors sleeping on the capitol floors, and the subsequent recall, what should be reiterated is that all of this happened in Wisconsin. Once the model progressive state for workers' rights and employee relations, Wisconsin was the first state to pass workers compensation legislation; the first to enact unemployment insurance laws; the birthplace of the American Federation of State, County and Municipal Employees (AFSCME); and one of the first three states to bar employment discrimination based on race, creed, and national origin. ${ }^{220}$ Of course, all of these accomplishments paled in comparison to being the first state to enact comprehensive collective bargaining legislation for the public sector. ${ }^{221}$ Wisconsin led the nation in progressive working trends in the early twentieth century, and the Badger State's models tended to end up all over the country. ${ }^{222}$ Thus, if Act 10 could desecrate collective bargaining rights in Wisconsin, many believed that collective bargaining rights were vulnerable everywhere. Even collective bargaining's staunchest supporters were left wondering: if Wisconsin was again acting as a harbinger for the nation, was the American labor movement fated to collapse?

Few issues are more partisan now than public sector collective bargaining rights. So much so that some public sector unions have been forced to become more political just to shield themselves from right-wing conservative attacks. While public unions are certainly hard to paint as true "victims" in the American labor scheme, it is important to note that much

\footnotetext{
218 See, e.g., April Girouard, Christie Embraces YouTube Stardom, Fox NEWs (Nov. 29, 2010), ttp://www.foxnews.com/politics/2010/11/29/christie-embraces-youtube-stardom.html [https://perma.cc/AL4F-GQWX]; Richard Pérez-Peña, Talking Tough and Drawing Viewers, New Jersey's Governor Is a YouTube Star, N.Y. TIMES, Nov. 30, 2010, at A26.

219 David A. Fahrenthold, Getting Chris Christie's Goat: Activists Try to Rile Up Governor, Pile Up Some YouTube Hits, WASH. POST (Dec. 20, 2014), https://www.washingtonpost.com/ politics/getting-chris-christies-goat-activists-try-to-rile-up-governor-pile-up-some-youtube-hits/2014/ 12/20/c1f4c29e-865d-11e4-9534-f79a23c40e6c_story.html [https://perma.cc/Q75L-KYX3].

220 See STEIN \& MARLEY, supra note 211, at 64-66.

221 Id.

222 Id.
} 
of their modern political activity may be reactionary. ${ }^{223}$ As such, agency fee opponents who criticize public sector unions in the courts for their reactionary political activities may be unjustly blaming the victim. Moreover, public unions find themselves in a unique "catch-22" if they are under fervent partisan attack and any response dooms their primary source of support in a legal challenge because their responsive activities are too political. For this reason, a modern and fair balancing of public union interests and activities in any First Amendment analysis is paramount to their future survival.

\section{THE FIRST AMENDMENT'S EVOLUTION AFTER ABOOD}

Abood also marked the beginning of a transformative period for the Supreme Court in First Amendment jurisprudence. Before the late 1970s, financial contributions were not "speech," associations had no expressive rights, campaign finance law as we now know it did not exist, and First Amendment principles in all forms were understood to be context specific and conditional. But beginning with Buckley and picking up speed in the 2000s, the Court has substantially modified First Amendment doctrine, protecting expression in more depth and expounding upon its interrelated association and expression principles. ${ }^{224}$ Some of these changes have aligned with the reasoning in Abood and other agency fee cases more than others, justifiably producing scholarly criticisms of modern First Amendment jurisprudence as "remarkably erratic and fragmented." 225

\footnotetext{
223 See, e.g., Matea Gold \& Melanie Mason, Labor Unions Rethinking Their Role in Politics, L.A. TiMES (Mar. 10, 2012), http://articles.latimes.com/2012/mar/10/nation/la-na-labor-endorse-20120311 [https://perma.cc/85NK-8H6G].

224 See generally Ronald K.L. Collins, Exceptional Freedom-The Roberts Court, the First Amendment, and the New Absolutism, 76 ALB. L. REV. 409 (2013) (noting a post-Chaplinsky resurgence by the Roberts Court recognizing categorical First Amendment exceptions and protections, which the author terms "new absolutism," wherein certain types of speech are absolutely protected while other categories are per se unprotected speech); G. Edward White, Justice Holmes and the Modernization of Free Speech Jurisprudence: The Human Dimension, 80 CALIF. L. REV. 391 (1992) (tracing the evolution of Justice Oliver Wendell Holmes's First Amendment interpretations, from his early common law influences and "clear and present danger" formula, to his later role as the "founder of modern First Amendment jurisprudence" with his speech-protective positions recognizing free speech as a central constitutional right).

225 Barry P. McDonald, The First Amendment and the Free Flow of Information: Towards a Realistic Right to Gather Information in the Information Age, 65 Оніо ST. L.J. 249, 251 (2004). Although McDonald's quote relates to newsgathering cases, his criticism is common regarding other types of First Amendment jurisprudence. See, e.g., Kathleen M. Sullivan \& Robert C. Post, Colloquy, It's What's for Lunch: Nectarines, Mushrooms, and Beef-The First Amendment and Compelled Commercial Speech, 41 LOY. L.A. L. REV. 359, 365-67 (2007) (describing "doctrinal instability and incoherence" in compelled-subsidy doctrine).
} 
As discussed in Part I and explained further below, agency fee doctrine touches on First Amendment principles relating to one's right to associate (or not to associate) with members of an organization for expressive purposes. But the extent to which this expressive association is protected-and how courts reconcile this relationship with the new expressive rights of the association itself-is still unclear. Agency fee doctrine may also relate to not having to speak, or sponsor another's speech, against one's will. But surely not all forced payments can be compelled speech, or else one may have a First Amendment right not to pay taxes or at least be entitled to a pro rata refund for taxes that support government initiatives with which one disagrees.

This Section examines First Amendment cases since Buckley and Abood in an attempt to flesh out how the concerns they raised work in other contexts and to identify doctrinal commonalities.

\section{A. Compelled Contributions as Compelled Speech in Campaign Finance}

As mentioned above in Part I, following Buckley, the Supreme Court in Abood extended First Amendment coverage to agency fees paid to a union for collective bargaining and contract-related expenses. ${ }^{226}$ Since then, the Court's entire agency fee jurisprudence up through and including Harris and Knox has insisted that the payment of all agency fees is expressive, despite scholarly arguments and a slew of other compelled contribution cases to the contrary. ${ }^{227}$

\section{Buckley Revisited with an Emphasis on Contributions' Expressive} Purpose and Abood

The Court's bedrock decision in Buckley v. Valeo was that financial contributions, made for the purpose of spreading a political message, are expressive conduct protected by the First Amendment. ${ }^{228}$ Buckley's impact on political campaigns over time cannot be overstated. ${ }^{229}$ However, when Abood was decided just a year later, Buckley's doctrinal significance was unknown and its reasoning untested. At times, the Abood Court's

\footnotetext{
226 See supra Section I.B.1.

227 See generally Norman L. Cantor, Forced Payments to Service Institutions and Constitutional Interests in Ideological Non-Association, 36 RUTGERS L. REV. 3, 14-15 (1983) (describing the Court's inappropriate acceptance of the extension of the First Amendment doctrine to forced monetary contributions).

228424 U.S. 1, 22 (1976) (per curiam).

229 See TOOBIN, supra note 74, at 150 (observing that the decision in Buckley was so significant that it practically "created an entirely new area of law," as campaign finance regulation was born out of the federal government's and states' frantic reconstruction of spending and contribution limits in response to its elusive guidance).
} 
inexperience with Buckley's newly crafted doctrine is apparent. For instance, the Court in Abood correctly relied on Buckley for the principle that contributions in support of a cause may be expressive and that restricting these contributions may infringe on a contributor's First Amendment rights. ${ }^{230}$ But it lost sight of Buckley's primary reasoning when it concluded that compelled contributions are the corollary expressive infringement to restrictions on contributions. ${ }^{231}$ The key inference in Buckley was that voluntary political contributions were expressive because the contributor intended the contribution as "support of an ideological cause." ${ }_{232}$ As such, compelled payments of any kind lose their expressive aspect because they are mandatory, irrespective of a person's intent or endorsement. ${ }^{233}$ Although the Court misinterpreted the expressive notion of forced agency fees in Abood, it has insisted on interpreting them as expressive ever since.

Despite the Abood Court's dubious reliance on Buckley for its holding that compelled political contributions are expressive, Buckley and its campaign finance descendants are still important features to any future agency fee analysis because of the distinctions they draw between "pure political speech" and expressive contributions. ${ }^{234}$ Unlike political expenditures - which Buckley viewed as essentially speech itself, invoking strict or exacting scrutiny analysis-Buckley distinguished expressive contributions as something less: ${ }^{235}$ an expressive or "symbolic act" that triggered a lesser level of scrutiny. ${ }^{236}$

\footnotetext{
230 See 431 U.S. 209, 234 (1977).

231 See id. at 234 ("The fact that the appellants are compelled to make, rather than prohibited from making, contributions for political purposes works no less an infringement of their constitutional rights." (footnote omitted)).

232 Id. at 235.

233 See Buckley, 424 U.S. at 21.

${ }^{234}$ McConnell v. FEC, 540 U.S. 93, 353 (2003); see also Buckley, 424 U.S. at 20-23.

235 Buckley, 424 U.S. at 64, 66. The standard established in Buckley and applied to political expenditures was one of "exacting scrutiny." Id. at 64. The Buckley Court, however, did not spell out exactly what this "exacting scrutiny" meant, and referred to its exacting scrutiny analysis as "strict," using other strict scrutiny language. $I d$. at 66 . Thus, the exacting scrutiny standard has been described more recently as being akin to strict scrutiny or perhaps lesser to an insignificant legal extent. See, e.g., Citizens United v. FEC, 558 U.S. 310, 366-67 (2010) (explaining that the exacting scrutiny test requires a "sufficiently important' governmental interest" and a 'substantial relation' between the disclosure requirement and that interest (quoting Buckley, 424 U.S. at 64, 66)). "Under exacting scrutiny, the [g]overnment may regulate protected speech only if such regulation promotes a compelling interest and is the least restrictive means to further the articulated interest." McCutcheon v. FEC, $134 \mathrm{~S}$. Ct. 1434, 1444 (2014) (citing Sable Commc'ns of Cal., Inc. v. FCC, 492 U.S. 115, 126 (1989)).

236 Buckley, 424 U.S. at 21.
} 
2. Modern Campaign Finance Decisions Expand on the Lesser Level of Scrutiny - "Closely Drawn Scrutiny"

In more recent campaign finance decisions, the Court has expanded upon the "less rigorous" level of scrutiny for political contributions Buckley alluded to. ${ }^{237} \mathrm{In}$ articulating this lesser standard, the Court has recognized an expressive nature in contributions but, like Buckley, derived their communicative value mainly from their symbolic support and facilitation of the recipient's expression, appraising it as less poignant than political expression of the donor herself. ${ }^{238}$ As such, to satisfy the closely drawn scrutiny test today, the government must demonstrate that its actions further "a sufficiently important interest" and use methods that are "closely drawn" to avoid unnecessary restrictions of First Amendment freedoms. ${ }^{239}$ Both the sufficiently important interest prong and the closely drawn prong of this scrutiny standard are less rigorous than the compelling interest and narrowly tailored/least restrictive requirements of strict and exacting scrutiny. But the question is: how much less?

In 2003, McConnell v. FEC challenged statutory limitations on political contributions based on a government interest in eliminating quid pro quo corruption. ${ }^{240}$ McConnell's application of closely drawn scrutiny is illustrative. The plaintiffs in McConnell argued that because the record was void of any evidence of instances of quid pro quo corruption, where "a federal officeholder has actually switched a vote" in exchange for soft money, Congress had failed to demonstrate a closely drawn sufficient state interest. ${ }^{241}$ The Court, however, disagreed, opting instead for a broader understanding of the relevant government interest in preventing corruption and a looser fitting of the law to the government's goal. ${ }^{242}$ The McConnell Court broadened the government interests from just preventing quid pro quo corruption (that according to the record did not exist) to include preventing the appearance of corruption, corruption more generally, or the "privileged access to and pernicious influence upon elected

\footnotetext{
237 McCutcheon, 134 S. Ct. 1434; McConnell v. FEC, 540 U.S. 93 (2001).

238 McCutcheon, 134 S. Ct. at 1444-45; McConnell, 540 U.S. at 94; see also Brief of PetitionerAppellant at 30, McCutcheon, 134 S. Ct. 1434 (No. 12-536). Particularly illustrative of the expressive nature of contributions, named plaintiff Shaun McCutcheon wished to make several $\$ 1,776$ donations to political causes and candidates that shared his values and approaches to public governance. Brief of Petitioner-Appellant, supra, at 30 . The precise donation amount (i.e., \$1776) was obviously chosen as a meaningful form of symbolism in itself. See Buckley, 424 U.S. at 20-21 (noting that limits on political contributions are only a "marginal restriction upon the contributor's ability to engage in free communication").

239 McCutcheon, 134 S. Ct. at 1445-46; Mc Connell, 540 U.S. at 94-96.

240540 U.S. at 95.

241 Id. at 149.

${ }^{242} I d$.
} 
representatives." 243 Under closely drawn scrutiny, McConnell also permitted government regulations to prevent corruption, even when those regulations were not finely tuned to accomplish that interest and involved a "significant interference" with First Amendment rights. ${ }^{244}$ The McConnell Court noted further that closely drawn scrutiny is flexible enough for courts to show 'proper deference to Congress' ability to weigh competing constitutional interests in an area [such as campaign finance law] in which it enjoys particular expertise." ${ }^{245}$ Three years later in Randall v. Sorrell, the Court described this weighing of interests when reviewing contribution limitations as a balancing test, where courts must uphold limitations that further an important state interest but strike down limitations that unduly inhibit the political process. ${ }^{246}$

Most recently, campaign finance decisions have adopted the more confined quid pro quo definition of corruption for supporting government interests but preserved the lower level of "closely drawn" judicial scrutiny for political contributions. ${ }^{247}$ McCutcheon v. FEC clarified that strict and exacting scrutiny (which applies to political speech and expenditures) requires a searching review that pays close attention to the "fit" between the asserted government interest and governments' policy choices. On the other hand, the "fit" between the government interest and governments' policy choices in closely drawn scrutiny (which applies to political contributions) need not be as close.

Taken together, recent campaign finance decisions articulate how to employ Buckley's less demanding closely drawn scrutiny standard today. Courts analyzing the government's chosen means with the closely drawn standard are prepared to uphold laws and regulations that further a government interest, even if the regulation is a not a near-perfect fit for that

243 Mc Cutcheon, 134 S. Ct. at 1469 (Breyer, J., dissenting).

244 Mc Connell, 540 U.S. at 136.

245 Id. at $137-38$.

246 See 548 U.S. 230, 247-48 (2006) (explaining that "closely drawn" scrutiny requires the courts to determine whether contribution limits are so low that they burden the political process). In addition to Randall, the Supreme Court expressly declined to overrule Buckley's distinction between independent expenditures and campaign contributions-and their scrutiny standards-in Citizens United v. FEC, 558 U.S. 310 (2010). That the Court declined to overrule the Buckley framework in Citizens United is significant because the Citizens United decision was a landmark case in which the Court not only struck down portions of the Bipartisan Campaign Reform Act of 2002 but also reversed its own precedent of allowing restrictions on political speech based on the speaker's corporate identity. Citizens United, 558 U.S. at 319, 365-66. Because it already represented an upheaval of campaign finance law, Citizens United would have been the perfect opportunity to overturn Buckley, had the Court wanted to.

247 Eleven years after McConnell, McCutcheon clarified that the "corruption" of Buckley is limited to quid pro quo corruption and not a broader understanding of political equality or the need to ensure broader political participation. McCutcheon, $134 \mathrm{~S}$. Ct. at 241-42. 
government interest. By not requiring a perfectly tailored fit, closely drawn scrutiny by implication suggests a regulation may be somewhat overinclusive or underinclusive and still pass constitutional muster. Finally, closely drawn scrutiny is flexible enough to allow judicial deference to legislative expertise.

\section{B. Compelled Third-Party Payments in Other Areas of the Law}

To be sure, even the Abood Court would concede that not all compelled contributions are compelled expression and not all compelled contributions of others' expression violate the First Amendment. Justice Byron White pointed out as much in his separate opinion in Buckley, reasoning that a belief otherwise would prove to be "entirely too much." 248 Moreover, the government enacts laws and regulatory schemes that compel payments or subsidies that are not constitutionally questionable, regardless of whether the payer agrees with their use. ${ }^{249}$ At the heart of this recognition are government-imposed taxes, which routinely compel individuals to make payments, even in support of government initiatives, services, or speech that they oppose. ${ }^{250}$ Paying taxes, however, is not expressive, even when government organizations use them to fund speech activities in furtherance of their legitimate regulatory purpose because the speech is attributed to the government as "government speech" and not an expressive endorsement by the individual taxpayers. Catherine Fisk and Margaux Poueymirou provide the apt example of a death penalty opponent who pays her taxes knowing some part of them will be used by prosecutors to advocate for the death penalty. ${ }^{251}$ By paying her taxes, she is not endorsing the death penalty and no one would associate her with the prosecutor's speech made on behalf of the state..$^{252}$

In addition to government speech, the government may also delegate regulatory functions to private third parties and compel individuals to subsidize their activities without implicating the First Amendment. When the third party engages in political speech, the constitutional issue is more complicated than pure government speech. The following Section examines lines of cases where government-compelled payments to a third party are

\footnotetext{
248424 U.S. 1, 262 (1976) (White, J., concurring in part and dissenting in part).

249 Id. at 262-63.

250 See United States v. Lee, 455 U.S. 252, 258-59 (1982) (noting that the Social Security system could not function if individuals were allowed to challenge Social Security payments because they were spent in a manner that went against their beliefs).

251 Catherine L. Fisk \& Margaux Poueymirou, Harris v. Quinn and the Contradictions of Compelled Speech, 48 LoY. L.A. L. REV. 439, 462 (2014).

${ }^{252}$ See id.
} 
and are not considered expressive. As the larger framework of this Article advocates, such payments are constitutional when part of a larger appropriate regulatory scheme or comprehensive government initiative.

The Court has focused on the regulatory purpose behind compelled payments to a third party in a series of cases addressing agriculturalsubsidy programs. In Glickman v. Wileman Bros. \& Elliott, Inc., the Court upheld a regulatory program that, among other things, required California fruit growers to contribute money to pay for general advertisements. ${ }^{253} \mathrm{Just}$ four years after Glickman, however, the Court struck down a similar requirement that mushroom farmers contribute to advertisements in United States v. United Foods, Inc. ${ }^{254}$ In United Foods, the Court distinguished the mushroom subsidies from the subsidies in Glickman because they were not part of a larger regulatory purpose, independent of the speech itself..255 In other words, the regulation creating the Mushroom Council and compelling the subsidies was for the exclusive purpose of advertisement (or expression), whereas in Glickman, "the mandated assessments for speech were ancillary to a more comprehensive [regulatory] program." 256

As illustrated in Glickman and United Foods, the government may, through legislation, delegate authority to a private entity and require individuals to pay those private-entity activities that are reasonably necessary to the delegated regulatory purpose. The Court has reaffirmed its authority to do this in a series of professional bar association cases where the government compels membership as part of granting access to a chosen profession. In Keller v. State Bar of California, the Court said that the bar could use compulsory dues only if the dues were "reasonably incurred for the purpose of regulating the legal profession or "improving the quality of the legal service available to the people of the State."'257 Like Abood, Keller granted a pro rata dues refund to members who objected to the bar's political or ideological expenditures. ${ }^{258}$

In sharp contrast to Abood and Keller's refund requirements, the Court upheld mandatory student activity fees at public universities in Board of Regents of the University of Wisconsin System v. Southworth. ${ }^{259}$ In Southworth, the Court unanimously upheld the permissibility of requiring

\footnotetext{
253521 U.S. 457, 460, 476-77 (1997).

254533 U.S. 405, 408-09 (2001).

$255 \mathrm{Id}$. at $414-16$.

256 Id. at 411.

257496 U.S. 1, 14 (1990) (quoting Lathrop v. Donohue, 367 U.S. 820, 843 (1961) (plurality opinion)).

${ }^{258}$ Id. at 16-17 (adopting "Abood obligation[s]" - meaning objecting payers were entitled to a refund of the bar association's political expenses - as sufficient protections for bar dues objectors).

259529 U.S. 217 (2000).
} 
college students to pay money each semester to a fund that subsidized student activities, part of which was given to groups with which they disagreed. ${ }^{260}$ Although the plaintiffs argued that under Abood and Keller this violated their First Amendment rights and that they were entitled to a pro rata refund for the political and ideological activities with which they disagreed, the Supreme Court rejected their claim. ${ }^{261}$ In doing so, the Court recognized that mandatory subsidies of objectionable speech infringed on students' First Amendment rights, but it also recognized the "important and substantial purpose[]" of student activity fees and "facilitat[ing] a wide range of speech." 262 Therefore, on balance, student activity fees passed constitutional muster without refunding students for objectionable expenditures. ${ }^{263}$ The Southworth Court, however, in reasoning that the university must provide some protection to its students' First Amendment interests, concluded that the university must allocate funding support in a viewpoint-neutral manner. ${ }^{264}$

Initially, Southworth's handling of compelled funding of political speech cannot be easily reconciled with that of Abood and Keller. In all three cases, there were compelled contributions to third parties. In all three cases, the challengers objected that their money was being spent to support political activities with which they disagreed. But in Southworth, the students were not entitled to a pro rata refund, while the complainants in Abood and Keller were. The difference between the three is that in Southworth, the Court upheld the compelled political and ideological contributions because it accepted the university's important interest in conveying a wide variety of messages, including those with which some students disagreed. ${ }^{265}$ According to the Southworth Court, the Abood/Keller approach of "limiting the required subsidy to [fund only] speech germane to the purpose" of the university was "unworkable" because determining what speech is germane to the university's purpose of exposing students to unexplored and diverse speech and ideas was contrary to the very goal the university sought to pursue. ${ }^{266}$ In Abood and Keller, by contrast, the Court

$260 I d$. at $220,231-32$.

${ }^{261} I d$. at $231-32$.

$262 I d$. at 231.

${ }^{263} \mathrm{Id}$.

${ }^{264}$ Id. at $233-34$.

265 Id. at 232-33. Moreover, the Southworth Court observed the impossibility of discerning which speech is germane to this university purpose, noting even in the labor union context, the Court has "encountered difficulties in deciding what is germane and what is not." Id. at 232. Therefore, in Southworth, the Court protected student First Amendment interests through requiring viewpoint neutrality, rather than through a pro rata refund.

266 Id. at 231-32. 
did not find a union or bar's political speech activities to be germane to its core purposes or goals. In other words, the distinction between Southworth, Keller, and Abood is not in whether there was compelled expression but in whether in the Court's view, the expression was sufficiently justified to meet the institution's core goals. The justifiability of compelled expression-if not accepted as a core institutional goal on its face as it was in Southworth - is determined and limited by the statutory duties, as it was in Glickman.

\section{RECONCILING MODERN FIRST AMENDMENT PRECEDENT WITH ABOOD AND Future Public SECTOR AGENCY FEE CASES}

Without overruling Abood, the current Court has modified First Amendment doctrine and expanded its protections in such a way that has reopened the constitutionality question of agency fees in the public sector. If the doctrinal inconsistencies were not clear enough, Justice Alito's notso-subtle dicta in Knox and Harris most certainly conveyed the message that the Court was finally prepared to overrule Abood and hold that the First Amendment forbids agency shop agreements and fees in the public sector. ${ }^{267}$ But a 4-4 decision in Friedrichs saved review of Abood's rationale for another day. ${ }^{268}$ With the Supreme Court now having a full complement of Justices and review of Janus v. AFSCME impending, the demise of Abood and the agency fees it permits may be imminent.

The preceding sections of this Article have attempted to show why any bright-line approach to agency fees in the public sector would be ill fitting. Public union activities are too transient for such an approach, and state statutes are too diverse amongst jurisdictions. Thus, this final Section proposes a workable compromise by suggesting that all agency fees are indeed some form of compelled expression-but should be treated as compelled political contributions in campaign finance, not as purely political speech. Under the modern compelled contribution analysis, the question of whether agency fees are "expressive" or "political" does not doom their constitutionality under strict or exacting scrutiny review. ${ }^{269}$ Instead, because the expressive purposes are more attenuated than pure speech, the limitations placed on contributions must be "closely drawn" to match a "sufficiently important [government] interest." "270 While compelled

267 See Harris v. Quinn, 134 S. Ct. 2618, 2643 (2014) (citing Knox v. Serv. Emps. Int'1 Union, Local 1000, 567 U.S. 298, 312 (2012)).

268 See Friedrichs v. Cal. Teachers Ass'n, 136 S. Ct. 1083 (2016)

269 McCutcheon v. FEC, 134 S. Ct. 1434, 1444 (2014) (quoting Buckley v. Valeo, 424 U.S. 1, 21, 25, 29 (1976) (plurality opinion)).

270 McConnell v. FEC, 540 U.S. 93, 94-95 (2001) (citing Buckley, 424 U.S. at 1, 25). 
contributions must be reasonable, legislatures should be accorded substantial deference in articulating their sufficiently important interests. ${ }^{271}$

Although this modern framework for compelled contributions is largely consistent with the Court's 1976 decision in Buckley, the Court has at times strayed from this appropriate understanding. ${ }^{272}$ However, with the Court's recent clarifications in McCutcheon, Buckley's analysis and "closely drawn scrutiny" appear to have been restored to their proper place for at least the time being.

\section{A. Adopting a Compelled Contribution Framework Respects the States' Choice of Regulatory Regime}

Adopting the compelled contribution framework for agency fee cases in the public sector is superior to a hard-line approach because it enables courts to give deference to state legislative efforts in the area of public sector collective bargaining. Under the framework articulated in McCutcheon, a case challenging campaign contribution limits under the First Amendment, the first step of the constitutional analysis is to determine whether the government has asserted a sufficiently important interest. ${ }^{273}$ Once the government asserts an important interest, courts can then assess whether that interest is linked to the policy choice necessitating the compelled limitation or contribution. ${ }^{274} \mathrm{McC}$ utcheon articulated that while strict and exacting scrutiny pay close attention to this fit between the important government interest and legislative policy choices, ${ }^{275}$ closely drawn scrutiny's flexibility allots for a less precise fit between the government interests and its chosen prophylactic scheme.

In McCutcheon and its predecessors, the state government's important interest in limiting contributions was to prevent quid pro quo corruption. In Abood and its successors, the state government's important interest in compelling contributions is to promote efficient labor relations and prevent "free riding." Both quid pro quo prevention and promoting efficient labor relations state interests are somewhat abstruse state interests, and their remedying statutes would be hard to justify as the best preventative matters and easy to dispute. However, while this imperfect fit most likely dooms

\footnotetext{
271 McCutcheon, 134 S. Ct. at 1480.

272 Compare Riddle v. Hickenlooper, 742 F.3d 922, 930 (10th Cir. 2014) (Tenth Circuit concluding that "exacting scrutiny" means a level of review just shy of strict scrutiny), with Worley v. CruzBustillo, 717 F.3d 1238 (11th Cir. 2013) (Eleventh Circuit finding that "exacting scrutiny" is little more than simple rational basis review).

273 McCutcheon, 134 S. Ct. at 1444.

274 See id. at 1441.

275 Id.
} 
Abood's (and McCutcheon's) state legislative purpose under a strict or exacting scrutiny analysis, these interests could survive under a "closely drawn" scrutiny analysis, especially if courts afford the same judicial deference to congressional expertise in labor statutes as it does to campaign finance.

Lesser attention to the fit between governments interests and policy choices is imperative if agency fees are to survive future First Amendment analysis because it is nearly impossible to prove that agency fees are the only means to efficient labor relations and preventing free riding. In an exclusive bargaining regime, what is strikingly damning to such a tailored attempt is that twenty-eight states and the federal government currently perform labor functions within a "right to work," or agency fee-free jurisdiction. While it could be argued that these are far less efficient labor regimes than those that permit agency fee collections in one form or another, accepting legislative bodies' propriety determinations requires removal of the strict, or even exacting, scrutiny standards of review.

\section{B. Adopting a Compelled Contribution Framework and Lesser Scrutiny Standard Is True to the First Amendment Doctrine}

Adopting the compelled contribution framework and lesser "closely drawn" scrutiny standard in agency fee jurisprudence is true to the foundational First Amendment principles of political speech and association. While this Article takes no position on Citizens United's controversial decision that organizational contributions are sufficiently expressive to trigger First Amendment protections, it recognizes that scholars have logically argued both for and against it. ${ }^{276}$ Largely uncontroversial, however, is the position that the spending of moneywhile not itself speech-is necessary for effective advocacy in the United States. As the Court has long recognized, "virtually every means of communicating ideas in today's mass society requires the expenditure of money." ${ }^{277}$ But contributions do not express a particular message or "communicate the underlying basis for the support." 278 For these reasons, since Buckley, the First Amendment has protected money's expressive value to a lesser extent than pure speech or expression. ${ }^{279}$

\footnotetext{
276 See, e.g., Nadia Imtanes, Should Corporations Be Entitled to the Same First Amendment Protections as People?, 39 W. ST. U. L. REV. 203 (2012).

277 Buckley v. Valeo, 424 U.S. 1, 19 (1976) (per curiam).

278 Id. at 21.

279 See, e.g., McConnell v. FEC, 540 U.S. 93, 122-32 (2001) (describing post-Buckley developments leading to need for increased regulation of campaign contributions); id. at 135-37 (comparing standards of scrutiny for speech against standards of scrutiny for political contributions).
} 
McCutcheon provided significant clarification as to what this extent actually was. While it declined to venture into the realm of strict scrutiny for financial expressions of any kind, McCutcheon applied "exacting scrutiny" to limitations on core First Amendment rights of political expression, such as political expenditures. ${ }^{280}$ However, because limits on contributions "impose a lesser restraint on political speech" than do limits on expenditures, they are subject to "a lesser but still "rigorous [closely drawn] standard of review." 281 With "closely drawn" scrutiny, "[e]ven a significant interference with protected rights ... may be sustained if the State demonstrates a sufficiently important interest and employs means closely drawn to avoid unnecessary abridgment of associational freedoms." ${ }^{282}$

To apply anything more than closely drawn scrutiny to agency fee analysis in First Amendment challenges would give more credence to compelled monetary contributions than the First Amendment intends. Even voluntary contributions to a union, until aggregated, have little expressive value. The contribution amount is small, and the purposes behind its donation can be vastly diverse. Union members, who voluntarily give money to a union, surely do not believe in every cause the union supports or even that their money is being well spent. But because their contribution is voluntary, it is accepted as a general expression of support of the union. Remove the voluntary aspect of contributions, and their expressive purpose is even less.

\section{Adopting the Compelled Contribution Model Means Courts Will Not Have to Choose Between Objecting Payers' and Unions'Rights}

Because of modern First Amendment law's disjointedness, choosing to adopt one precedent over another requires a bit of cherry picking. ${ }^{283}$ Agency fee objectors who claim such fees violate payers' First Amendment rights are guilty of this because in preserving the rights of nonmembers, they ignore the rights of unions and union members to engage in First Amendment activities. Their attention to dissenters is not wholly inconsistent with the individual speech protections of the First Amendment,

\footnotetext{
280 See McCutcheon, 134 S. Ct. at 1444 (quoting Buckley, 424 U.S. at 44). The "exacting scrutiny" standard articulated in $\mathrm{McCutcheon}$ is familiarly close to strict scrutiny. Id. ("Under exacting scrutiny, the Government may regulate protected speech only if such regulation promotes a compelling interest and is the least restrictive means to further the articulated interest."); see also Sable Commc'ns of Cal., Inc. v. FCC, 492 U.S. 115, 126 (1989) (elaborating on standards of scrutiny for regulation of constitutionally protected speech).

281 McCutcheon, 134 S. Ct. at 1437 (quoting Buckley, 424 U.S. at 29).

282 Id. at 1444 (quoting Buckley, 424 U.S. at 25) (internal quotation marks omitted).

283 See supra note 229.
} 
which place a premium on unfettered discourse. However, on the campaign spending side, because the Court recognizes that restricted spending is less of an encroachment than restricted speech, it has developed a more reasonable balancing method of individual infringements with other interests.

In prior agency fee cases, the Court has assessed the constitutionality of agency fee agreements by balancing the First Amendment rights of agency fee payers against the government's interest in combatting free riders and promoting labor peace. But this distorts the balancing scale because it portrays only one side (the payers) as having First Amendment rights, while portraying the other as having only a statutory interest. Citizens United's expansion of First Amendment rights to expressive groups, however, necessitates a rezeroing of this scale. ${ }^{284}$ If unions enjoy First Amendment protections as expressive associations, should not their rights also factor into this agency fee analysis? Should not the First Amendment rights of a union, composed of real working people and governed by democratic rules and majority consensus, receive at least the same rights to influence the political process as an "artificial... invisible ... and existing only in contemplation of law" corporation?285 Moreover, if courts are going to protect nonmembers from being forced to subsidize activities, should not they also protect unions from being forced to subsidize nonmember activities and prohibit a duty of fair representation regime? ${ }^{286}$

\section{Suggestions for "Closely Drawn" Statutory Frameworks}

If the Court adopts the framework for agency fee analysis articulated in this Article, the logical next inquiry will consider what exactly a closely drawn statutory framework that passes constitutional muster looks like. In large part, I leave this query for future scholarly works but with the following broad suggestions.

First, although "closely drawn" scrutiny will tolerate even "significant" right infringements, legislative and union bodies advocating for agency fees should consider statutory models that limit this infringement to the utmost extent. ${ }^{287}$ For example, nonmember agency fee payers should be able to participate in union surveys within their collective

\footnotetext{
284 See 558 U.S. 310, 376 (2010) (Roberts, C.J., concurring) (“Congress may not prohibit political speech, even if the speaker is a corporation or union.").

285 Tr. of Dartmouth Coll. v. Woodward, 17 U.S. 518, 636 (1819).

286 See Sweeney v. Pence, 767 F.3d 654, 657 (7th Cir. 2014) (affirming constitutionality of statute providing that nonmembers could not be required to pay dues, fees, or assessments of labor unions).

287 See McCutcheon, 134 S. Ct. at 1444.
} 
bargaining unit when such surveys impact the union collective bargaining strategies that their fees subsidize. ${ }^{288}$ Moreover, they should be able to vote on union proposals, contract ratification, and other elective matters. Because their agency fees are going to support these union activities, they should be given the same opportunities for voice as other members in these union matters. Many unions already do survey an entire bargaining unit on certain employment issues, and in future challenges, this fact should be pertinent to a court's analysis under "closely drawn" scrutiny analysis. However, in future legislative schemes, lawmakers should consider mandating such voter rights for agency-fee-subsidized representatives. Once lawmakers establish this floor, unions may also choose to experiment with other additional means of promoting agency-fee-payer voice and participation in internal union matters. For example, they may undertake certain controversial union activities only after approval by a voting majority (or supermajority) of their particular bargaining unit.

Second, limiting the rights infringements of agency fees may be brought about by limiting the agency fees themselves. Obviously, if the Court adopts the "closely drawn" framework for agency-fee-permitting statutes, the more detailed the regulatory language articulating the representative's duties, bargaining subjects, and relation to the limited fee, the better. ${ }^{289}$ Seemingly vague agency fee limits or arbitrary proportionalities of fees without justification will probably fail this scrutiny standard. ${ }^{290}$

After specific regulatory language is drafted, unions themselves may want to consider what is not explicitly included in the defined duties of an exclusive bargaining representative and use these exclusions to create their own limited agency fee models with the nonmembers they represent. For example, while the duties of an exclusive bargaining representative generally include "contract administration," they usually do not include language for "free contract administration." Thus, perhaps unions could offer a lesser agency fee calculation for those nonmembers who agree to contract away their right to obtain free union representation in grievances.

288 See generally Melanie Stallings Williams \& Dennis A. Halcoussis, Unions and Democracy: When Do Nonmembers Have Voting Rights?, 9 J. BUS. \& TECH. L. 213 (2014) (describing the rights of agency fee payers to vote on union internal matters related to terms and conditions of employment).

289 Id.

290 See Lehnert v. Ferris Faculty Ass'n, 500 U.S. 507, 532 \& n.6 (1991) (criticizing Justice Scalia’s attention to the statutory duties approach outlined in his concurring and dissenting opinion). In his critique, Justice Blackmun noted the generality of state laws authorizing agency shops, which he considered a "poor criteri[ion]" for determining which charges violate the First Amendment. Id. at 526. Note, however, that statutory schemes authorizing public sector collective bargaining and agency fees have become much more specific than they were in 1991 when Lehnert was decided. 
These members could instead be charged a fair market rate for the union's grievance representation services, should they end up needing it during a year when they had waived that right.

\section{CONCLUSION}

With Janus v. AFSCME, the Court may finally have the last word on agency fees in the public sector. But given the vast diversity in state collective bargaining statutes and agency fee provisions, the legitimate and complex interests at stake, and the evolving contours of First Amendment jurisprudence, it would be unwise to entirely foreclose the possibility of agency shop agreements and fees. A case-by-case analysis of agency fees and their relation to a union's statutory duties is a better fit for our modern jurisprudence and our ever-changing political reality. Reexamining agency fees in the public sector through the compelled contribution doctrine and closely drawn scrutiny standard of campaign finance law offers this kind of flexibility. 
N ORTHW ESTER N UNIVERSITY L A W RE VIEW 